\title{
Resolving cryptic species complexes of major tephritid pests
}

\author{
Jorge Hendrichs', M. Teresa Vera ${ }^{2,3}$, Marc De Meyer ${ }^{4}$, Anthony R. Clarke \\ I Insect Pest Control Section, Joint FAO/IAEA Division of Nuclear Techniques in Food and Agriculture, Vien- \\ na, Austria 2 Cátedra Terapéutica Vegetal, Facultad de Agronomía y Zootecnia (FAZ), Universidad Nacional \\ de Tucumán (UNT), San Miguel de Tucumán; Argentina 3 Consejo Nacional de Investigaciones Cientificas y \\ Técnicas (CONICET), Argentina 4 Royal Museum for Central Africa, Invertebrates Unit, Leuvensesteenweg \\ 13, B3080 Tervuren, Belgium 5 School of Earth, Environmental and Biological Sciences, Queensland Univer- \\ sity of Technology (QUT), GPO Box 2434, Brisbane, QLD 4001, Australia
}

Corresponding author: Jorge Hendrichs (j.hendrichs@iaea.org)

$\frac{\text { Academic editor: P. Stoev | Received 25 October } 2015 \text { | Accepted 6 November } 2015 \text { | Published } 26 \text { November } 2015}{\text { http://zoobank.org/8EB1ECA2-719E-4759-8C1B-38B8DF00F17F }}$

Citation: Hendrichs J, Vera MT, De Meyer M, Clarke AR (2015) Resolving cryptic species complexes of major tephritid pests. In: De Meyer M, Clarke AR, Vera MT, Hendrichs J (Eds) Resolution of Cryptic Species Complexes of Tephritid Pests to Enhance SIT Application and Facilitate International Trade. ZooKeys 540: 5-39. doi: 10.3897/zookeys.540.9656

\begin{abstract}
An FAO/IAEA Co-ordinated Research Project (CRP) on "Resolution of Cryptic Species Complexes of Tephritid Pests to Overcome Constraints to SIT Application and International Trade” was conducted from 2010 to 2015. As captured in the CRP title, the objective was to undertake targeted research into the systematics and diagnostics of taxonomically challenging fruit fly groups of economic importance. The scientific output was the accurate alignment of biological species with taxonomic names; which led to the applied outcome of assisting FAO and IAEA Member States in overcoming technical constraints to the application of the Sterile Insect Technique (SIT) against pest fruit flies and the facilitation of international agricultural trade. Close to 50 researchers from over 20 countries participated in the CRP, using coordinated, multidisciplinary research to address, within an integrative taxonomic framework, cryptic species complexes of major tephritid pests. The following progress was made for the four complexes selected and studied:

Anastrepha fraterculus complex - Eight morphotypes and their geographic and ecological distributions in Latin America were defined. The morphotypes can be considered as distinct biological species on the basis of differences in karyotype, sexual incompatibility, post-mating isolation, cuticular hydrocarbon, pheromone, and molecular analyses. Discriminative taxonomic tools using linear and geometric morphometrics of both adult and larval morphology were developed for this complex.
\end{abstract}

Copyright Jorge Hendrichs et al. This is an open access article distributed under the terms of the Creative Commons Attribution License (CC BY 4.0), which permits unrestricted use, distribution, and reproduction in any medium, provided the original author and source are credited. 
Bactrocera dorsalis complex - Based on genetic, cytogenetic, pheromonal, morphometric, and behavioural data, which showed no or only minor variation between the Asian/African pest fruit flies Bactrocera dorsalis, $B$. papayae, $B$. philippinensis and $B$. invadens, the latter three species were synonymized with $B$. dorsalis. Of the five target pest taxa studied, only $B$. dorsalis and $B$. carambolae remain as scientifically valid names. Molecular and pheromone markers are now available to distinguish $B$. dorsalis from $B$. carambolae.

Ceratitis FAR Complex (C. fasciventris, C. anonae, C. rosa) - Morphology, morphometry, genetic, genomic, pheromone, cuticular hydrocarbon, ecology, behaviour, and developmental physiology data provide evidence for the existence of five different entities within this fruit fly complex from the African region. These are currently recognised as Ceratitis anonae, C. fasciventris (F1 and F2), C. rosa and a new species related to C. rosa (R2). The biological limits within C. fasciventris (i.e. F1 and F2) are not fully resolved. Microsatellites markers and morphological identification tools for the adult males of the five different FAR entities were developed based on male leg structures.

Zeugodacus cucurbitae (formerly Bactrocera (Zeugodacus) cucurbitae) - Genetic variability was studied among melon fly populations throughout its geographic range in Africa and the Asia/Pacific region and found to be limited. Cross-mating studies indicated no incompatibility or sexual isolation. Host preference and genetic studies showed no evidence for the existence of host races. It was concluded that the melon fly does not represent a cryptic species complex, neither with regard to geographic distribution nor to host range. Nevertheless, the higher taxonomic classification under which this species had been placed, by the time the CRP was started, was found to be paraphyletic; as a result the subgenus Zeugodacus was elevated to genus level.

\section{Keywords}

Anastrepha fraterculus, Bactrocera carambolae, Bactrocera dorsalis, Ceratitis anonae, Ceratitis fasciventris, Ceratitis rosa, Zeugodacus cucurbitae, integrative taxonomy, Sterile Insect Technique, sibling species

\section{Introduction}

Tephritid fruit flies (Diptera: Tephritidae) are among the world's worst pests of agriculture, being of major economic importance in nearly all tropical, subtropical and temperate countries (Cavalloro 1983, White and Elson-Harris 1994). By laying their eggs directly into fruit, where the maggots feed and develop, these pest species cause enormous devastation to both food production and international trade in spite of often intensive insecticide applications. They are among the primary causes of poverty, malnutrition and poor production and trade in fresh horticultural commodities in large areas of tropical developing countries, impeding the development of lucrative and labour-intensive fruit and vegetable-based agroindustries in rural areas (Waterhouse 1993, Allwood and Leblanc 1996).

The study of the biology and management of tephritids requires significant international attention to overcome transboundary hurdles and to assist the global community in developing and validating more environment-friendly fruit fly suppression systems to support viable fresh fruit and vegetable production and export industries. Such international attention has resulted in the successful development and validation of a Sterile Insect Technique (SIT) package for the Mediterranean fruit fly, Ceratitis capitata (Wiedemann, 1824) (Dyck et al. 2005). R\&D support for this pest species 
is diminishing due to successful integration of the SIT into area-wide integrated pest management (AW-IPM) programmes to manage C. capitata populations (Enkerlin 2005). On the other hand there is increased demand from Africa, the Asia-Pacific and Latin America to address other major tephritid species or groups of economic importance. Some of these major pest fruit fly species occur within cryptic species complexes that include taxonomically described species that may actually be geographical variants of the same species. Conversely, some fruit fly populations grouped taxonomically within the same pest species display different biological and genetic traits, including reproductive isolation, which suggest that they are different species (Clarke and Schutze 2014). This uncertain taxonomic status has important practical implications on the effective development and use of the SIT against such pest complexes where the species under mass-rearing is not the same as the population occurring in the target area. Uncertainty of taxonomic status can also result in the incorrect establishment of trade barriers for agricultural commodities that are hosts of pest tephritids.

The resolution of some of the taxonomic uncertainties that surround major cryptic species complexes is therefore critical both for integrated SIT application and for subtropical and tropical countries to overcome non-tariff trade barriers, enabling them to export their fresh fruit and vegetable commodities to international markets. In particular, it is essential that the sterile males from such species complexes produced in regional fruit fly rearing facilities and destined for release in different countries or regions are behaviourally fully compatible with the target native fruit fly pest populations in the various recipient regions (Cayol et al. 2002). If the taxomomic status of species complexes remained unresolved, it would be difficult or impossible to achieve this desirable goal.

To address these issues, a major international collaboration was initiated in 2010 under the auspices of the Joint Food and Agriculture Organization / International Atomic Energy Agency (FAO/IAEA) Programme on Nuclear Techniques in Food and Agriculture. This paper summarises the goals, achievements and results of this coordinated research project that are compiled in this special issue of Zookeys (2015, Special Issue 540).

\section{Approach}

During a Consultants' Meeting, held from the $6^{\text {th }}$ to $10^{\text {th }}$ of July 2009 in Vienna, Austria, the potential for conducting co-ordinated $\mathrm{R} \& \mathrm{D}$ in this area was assessed, and the major tephritid pest complexes were discussed and prioritised in terms of economic importance and potential for SIT application. Three complexes, the Anastrepha fraterculus complex (Latin America), the Bactrocera dorsalis complex (Asia and Pacific, Africa), and the Ceratitis FAR (= C. anonae Graham, 1908, C. fasciventris (Bezzi, 1920), C. rosa Karsch, 1887) complex (Africa) were confirmed to be of priority. The possibility that Bactrocera cucurbitae (Coquillett, 1899) (Asia and Pacific, Africa) also represents a species complex was evaluated and considered a lower, but still important, priority. In 
each of these groups (Figure 1), questions were raised concerning the validity of some of the described species, the capacity to diagnose described species, or the strong $a$ priori evidence that unrecognised sibling taxa may occur.

A proposal for an FAO/IAEA Co-ordinated Research Project (CRP) on "Resolution of Cryptic Species Complexes of Tephritid Pests to Overcome Constraints to SIT Application and International Trade" was formulated and approved for the period 2010-2015. The specific objectives of this CRP were to define, using an integrative taxonomic approach (Schlick-Steiner et al. 2010), the species limits within the target complexes, and to develop robust species-specific diagnostic tools.

This international research network was operated under the IAEA Research Contract Programme and included 22 research teams. Other research teams also par-

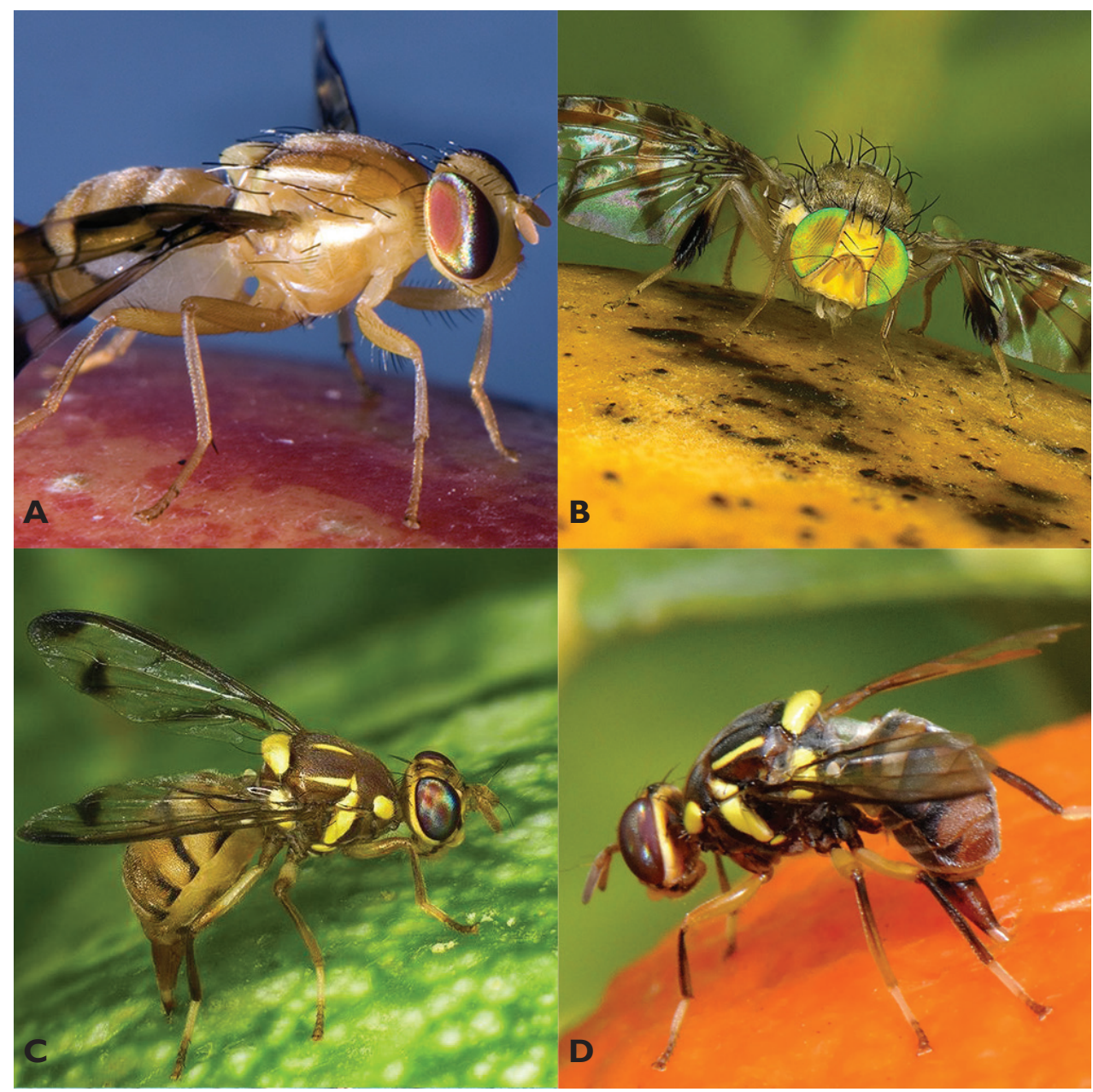

Figure I. Habitus image of a representative of the four cryptic species complexes. A Anastrepha fraterculus B Ceratitis rosa (R2 type) C Zeugodacus cucurbitae D Bactrocera dorsalis. Photo credits: A Michal Hoskovec, B and C Antoine Franck, D Ana Rodriguez. 
ticipated directly or indirectly and were fully funded by their institutions and governments. Overall close to 50 researchers from over 20 countries from all continents participated at one time or another during the six years of the CRP (2010-2015).

Research networks were established to (1) encourage close collaboration among institutes from developed and developing countries, (2) provide a forum for information exchange between scientists, and (3) embrace a focused approach to the development, capacity building and technology transfer of environment-friendly technologies. A worldwide network of partners provided representative samples of the fruit fly populations in order to assess the genetic diversity throughout the distributional ranges of the members of each complex. A generic protocol for collection and shipment of live and dead insects for vouchering, rearing, morphological and morphometric studies, chemical ecology and molecular assays was developed at the start of the CRP and used for distribution of material between the participating research units. Whenever possible, colonies of populations were established at the FAO/IAEA Agriculture and Biotechnology Laboratories in Seibersdorf, Austria, to be able to carry out field cage cross-mating studies that would not have been acceptable at other locations due to quarantine regulations and the risk of pest establishment.

During the implementation of the CRP, four Research Co-ordination Meetings (RCMs) were held to review research progress and to agree on future research directions and activities: the first RCM in Vienna, Austria from 2-6 August 2010, the second RCM in Brisbane, Australia from 31 January-3 February 2012, the third RCM in Tucumán, Argentina from 26-31 August 2013 and the fourth and final RCM in La Réunion, France from 1-5 June 2015.

\section{Situation Analysis at the Start of the CRP and Ouputs for Each Complex}

\subsection{Anastrepha fraterculus Complex Situation Analysis}

The South American fruit fly, Anastrepha fraterculus (Wiedemann, 1830) s.l., is present in most countries of the Americas from the USA to Argentina (Hernández and Aluja 1993, Steck 1999, Zucchi 2007). Its centre of diversity is the South American subcontinent, where formerly it was thought to occurr in two, possibly unconnected bands: one along the western edge, including both highland and lowland areas of the Andean range, and the other along the east coast. However, recent data indicate its presence in parts of the Brazilian Amazon basin (Zucchi et al. 2011). It has been reported to infest about 110 host plants including major fruit crops (Norrbom and Kim 1988, Zucchi 2000, 2015, Norrbom 2004). The presence of this highly destructive pest results in quarantine restrictions for fruit export to many countries (Steck 1999).

The high levels of variability found among different populations throughout the geographical range of $A$. fraterculus led to the conclusion that it is a complex of cryptic species rather than a single biological entity (Stone 1942, Morgante et al. 1980, Malavasi and Morgante 1982, Solferini and Morgante 1987, Steck 1991, Steck and 
Sheppard 1993, Selivon 1996, Hernández-Ortiz et al. 2004). Differences have been reported based mainly on morphology, pest status and genetics (including karyotype, isozyme and molecular analyses); these are reviewed in Steck (1999) and some aspects discussed in subsequent studies (McPheron et al. 1999, Norrbom et al. 1999, Gomes Silva 2000, Smith-Caldas et al. 2001, Aluja et al. 2003, Hernández-Ortiz et al. 2004, Barr et al. 2005, Selivon et al. 2005, Goday et al. 2006, Selivon and Perondini 2007, Silva and Barr 2008, Prezotto 2008, Cáceres et al. 2009). However, in order to establish how much of this variation reflects population level variation, and how much reflects unrecognised cryptic species diversity, it is necessary to systematically correlate these genetic and morphological differences with the existence of reproductive isolation and other life history related traits (hosts, demography, etc).

Reproductive incompatibility has been reported both at pre- and post-zygotic levels between some $A$. fraterculus populations. At the pre-zygotic level, mating compatibility was evaluated among different populations from South America, involving lowland (Peru) and highland (Colombia) areas from the Andean region, and the south-eastern part of the continent (Brazil and Argentina). Most of the populations were shown to have some level of incompatibility with each other and thus appeared sexually isolated. Flies of different populations were often sexually active at different times of the day suggesting different sexual behaviour (Selivon 1996, Vera et al. 2006, Cáceres et al. 2009).

Post-zygotic studies between two populations from Brazil (Selivon et al. 1999) and between one Argentinean population and one Peruvian population (Cáceres et al. 2009) found partial hybrid inviability and sex ratio distortion confirming the existence of post-zygotic barriers. In the former case, cytological, isozyme and molecular studies revealed differences among groups (Malavasi and Morgante 1982, Selivon 1996, Selivon et al. 2005, Goday et al. 2006); while for the latter case, differences between groups were also found in terms of male sex pheromones and karyotypes (Cáceres et al. 2009).

The combined results of these studies suggested the existence of seven different biological entities referred to as: Anastrepha sp. 1 aff. fraterculus (Brazilian 1 morphotype) (Yamada and Selivon 2001), Anastrepha sp. 2 aff. fraterculus (Brazilian 2 morphotype) (Yamada and Selivon 2001), Anastrepha sp. 3 aff. fraterculus (Brazilian 3 morphotype) (Selivon et al. 2004), Anastrepha sp. 4 aff. fraterculus (Peruvian morphotype) (Selivon et al. 2004), A. fraterculus Mexican morphotype (Hernández-Ortiz et al. 2004), A. fraterculus Andean morphotype and $A$. fraterculus Venezuela coastal lowlands (Steck 1991).

Although previous studies provided strong evidence supporting the existence of several biological species, major knowledge gaps still existed in 2010. In particular, the described studies used different methodologies, did not use the same identified biological material and, most importantly, did not include all of the morphotypes. Therefore, in order to be able to formally describe and name these putative species, it was considered critical to apply a standardised, complete set of methodologies to all populations from the entire geographic distribution range in a comprehensive integrative taxonomy study. This would allow the characterization of each putative species and would provide sound diagnostic tools for addressing the related management and trade issues. 
Definition of species limits and formal naming of these putative species will be relevant for plant protection authorities in determining which of them may or may not be quarantine pests. This would immediately allow some countries to gain access to international fresh fruit markets for those countries and commodities which can be determined to be outside the geographic and host range of correctly delimited $A$. fraterculus s.s. In addition, detailed studies on pest status, host range, economic impact and distribution would minimize any possible impact on trade between South American countries. Furthermore, knowing species boundaries and their levels of sexual compatibility within the complex would enable the implementation of the SIT.

\subsection{Outputs on the Anastrepha fraterculus complex}

Colonies from five $A$. fraterculus morphotypes (Mexican, Andean, Peruvian, Brazilian 1 and Brazilian 3) were established and used for behavioural, chemical, cytological, molecular and larval morphology studies. Linear and geometric morphometry were validated as tools for morphotype discrimination. Comprehensive morphometric studies supported the existence of eight morphotypes: the seven reported previously and a new Equadorian morphotype (Hernández-Ortiz et al. 2012, 2015).

Guidelines for performing mating compatibility field cage tests were developed. Reproductive compatibility studies were performed among the five morphotypes. Among the combinations studied, morphotypes were incompatible at the pre- and post-zygotic level (Rull et al. 2012, 2013, Devescovi et al. 2014). Male calling and courtship behaviour were recorded for four morphotypes. Sexual behaviour studies helped to identify behavioural characteristics that allowed distinct morphotype descriptions such as time of sexual activity, acoustical signals and sequence of courtship behaviour (Rull et al. 2012, 2013, Devescovi et al. 2014, Dias et al. in press). One post-copulatory study revealed differences in sperm storage and remating propensity between the Peruvian and Brazilian 1 morphotypes (Abraham et al. 2014). Hybrid females tended to mate with hybrid males and as a result Segura et al. (2011) suggested that hybridization is a possible speciation mechanism. In all combinations analysed, post-zygotic isolation was found to be weaker than pre-zygotic (Devescovi et al. 2014). Wolbachia was detected in several morphotypes (Cáceres et al. 2009, Lima 2015, Lima et al. unpublished data) and more in-depth studies aiming to characterize these strains are in progress.

The chemical profiles of the male pheromones and cuticular hydrocarbons of these five morphotypes were characterized as complex blends that were qualitatively and quantitatively unique for the different morphotypes (Břízová et al. 2013, Gonçalves et al. 2013, Vaníčková et al. 2012, 2015a,c,d, Milet-Pinheiro et al. 2015). The description of the mitotic karyotypes from the Mexican, Colombian and Equadorian morphotypes, from which information was absent or incomplete, allowed confirming that karyotypes are unique for each morphotype (Canal et al. unpublished data). The polytene chromosome map for one morphotype was constructed (Gariou-Papalexiou 
et al. unpublished data). Internal Transcriber Spacer 1 (ITS 1) was found to be a good molecular marker to identify different groups (Sutton et al. 2015). Microsatellites were developed (Lanzavecchia et al. 2014) and proved to be successful to discriminate among morphotypes (Lima et al. unpublished data, Manni et al. 2015). The phylogenetic relationships of Andean-Ecuadorian populations were determined with other molecular markers (Ludeńa et al. 2011).

Based on all the collected evidence it is now possible to describe four morphotypes as new species with the exception of the three Brazilian morphotypes for which it is still necessary to solve problems with the unknown origin of the holotype male of Anastrepha fraterculus (Wiedemann) and the new Ecuadorian morphotype from which further studies are required for an integrative description (Hernández-Ortiz et al. 2015). A manuscript with the description of the new species is in preparation (V. HernándezOrtiz personal communication) and improved diagnostic tools are now available based on morphology, molecular markers, chemical profiles, cytology and sexual behaviour.

The knowledge and gaps identified at the start of the CRP, as well as the progress made by the end of the CRP in addressing the gaps identified for the $A$. fraterculus complex are summarized in Table 1.

\subsection{Bactrocera dorsalis Complex Situation Analysis}

Across Asia and the Pacific the fruit fly subfamily Dacinae contains some 47 recognised pest species (Drew and Romig 2013). Of these, eight were recognized within the Bactrocera dorsalis complex, with some being the most economically damaging of all pest species within the subfamily (Drew and Hancock 1994, Clarke et al. 2005). Losses caused by $B$. dorsalis complex species include destruction of crops, restriction of international trade, and the establishment of a range of quarantine and regulatory activities carried out by various regional governments.

Background research on these flies has generated data on diagnostics, field surveillance, quarantine strategies, field pest control, and market access protocols (e.g. Tan and Nishida 1996, 1998, Muraji and Nakahara 2002, Naeole and Haymer 2003, Smith et al. 2003, Armstrong and Ball 2005). But the key knowledge gap of the $B$. dorsalis complex was a lack of consensus on species limits of the major pest species in the complex, particularly B. dorsalis s.s. (Hendel, 1912), B. papayae (Drew \& Hancock, 1994), B. philippinensis (Drew \& Hancock, 1994), B. carambolae (Drew \& Hancock, 1994) and B. invadens (Drew, Tsuruta \& White, 2005) (Clarke et al. 2005, Drew et al. 2005, Wee and Tan 2005, Ebina and Ohto 2006, Drew et al. 2008). Failure to resolve the taxonomic status of the members of this complex prevented further development towards SIT integration into AW-IPM programmes against these pest insects and limited international horticultural trade.

Background research on the taxonomy of the $B$. dorsalis complex has been unable to provide definitive identification of some species (Clarke et al. 2005). This has confounded collecting associated host plant records and defining geographic distributions. It was 


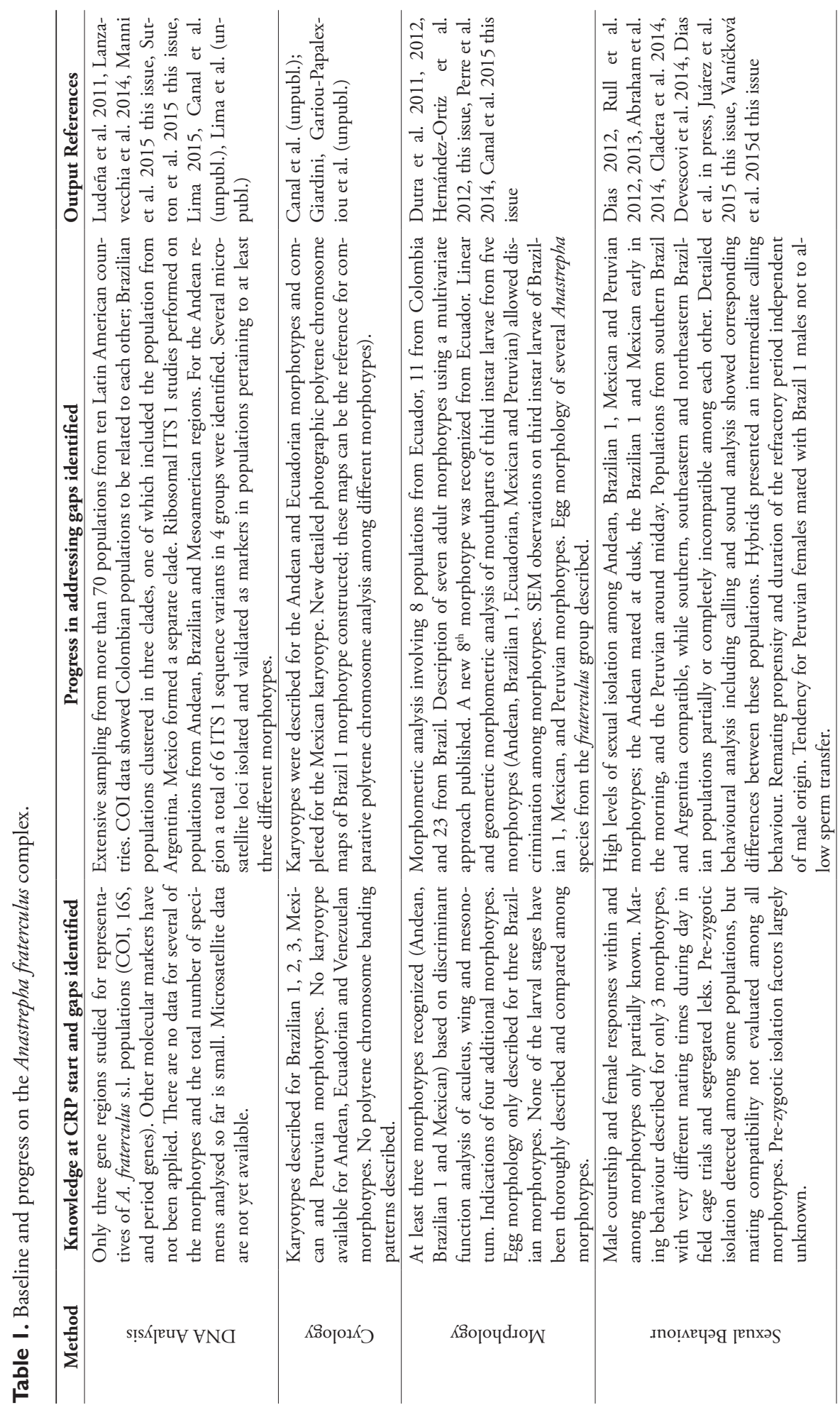




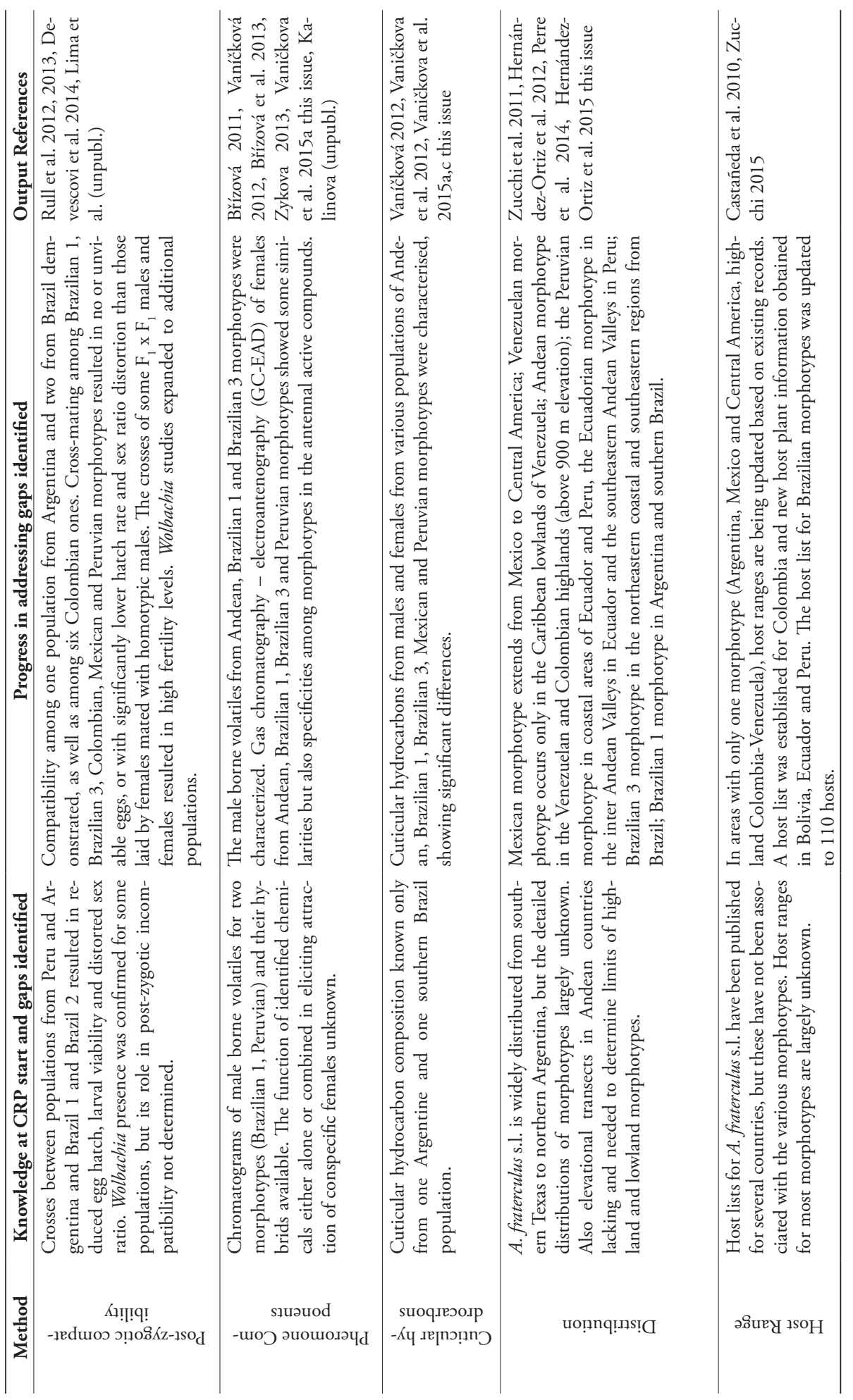


considered absolutely essential that the species be accurately identified to be able to apply AW-IPM field programmes that include a SIT component. Because the trade implications and response systems to detections and/or incursions are different for all members in the complex, "near-enough" identification is, unfortunately, not good-enough. Consequently countries have difficulty overcoming the phytosanitary barriers to export-trade to major importers such as Australia, Japan, Europe, New Zealand, South Africa, and the USA. Another severe problem would arise if one member of the complex is detected or becomes established in a country, but is unable to be differentiated from others in the complex. In this case that country would then be forced to admit that all members of the complex may in fact be present, which would result in extended trade embargoes.

Therefore a comprehensive integrative taxonomy approach involving biological, morphological, chemo-ecological and molecular studies of the various members of the $B$. dorsalis complex were needed to: (1) resolve species limits by seeking a consensus result from different tests; (2) examine congruence between data from the different approaches to either support taxonomic revision or retain existing species status; and (3) develop robust diagnostic tools for the identified species.

\subsection{Outputs on Five Priority Species in the Bactrocera dorsalis Complex}

Quantified cross-species field-cage mating trials, as described in the FAO/IAEA/USDA Quality Control Manual (FAO/IAEA/USDA 2014), were completed for B. dorsalis s.l. populations from China, Kenya, Malaysia, Pakistan, the Philippines, Suriname and Thailand. Results presented in Schutze et al. (2013), Bo et al. (2014), and Chinvinijkul et al. (2015) demonstrated pre- and post-zygotic mating compatibility between all target taxa except for crosses involving $B$. carambolae, which always showed some level of sexual isolation from the other taxa. Post-zygotic isolation tests up to three generations were carried out for crosses involving $B$. dorsalis s.s. (China and Pakistan) and $B$. invadens; no evidence for hybrid incompatibility was detected (Bo et al. 2014).

Chemical components and ratios of sex pheromone stored in male rectal gland and emitted during courtship after feeding on methyl eugenol (ME) were determined qualitatively and quantitatively for $B$. dorsalis s.s., B. invadens, B. papayae and B. philippinensis. The four ccomplex members had identical volatile emission profiles and rectal pheromonal components consisting of 2-allyl-3,4, dimethoxyphenol (DMP) and Econiferyl alcohol (E-CF) (Tan et al. 2011, 2013), and the ratios of DMP: E-CF were not significantly different between the different members. Probit analysis showed that the responsiveness of these four members to $\mathrm{ME}$ was similar as their $\mathrm{ED}_{50}$ values (= dose at which $50 \%$ of the population responded) were not significantly different (Hee et al. 2015a). However, differences were found for B. carambolae.

Wing shape variation analysed through geometric morphometrics was used for the first time in the $B$. dorsalis complex (Schutze et al. 2012a,b, Krosch et al. 2013). Variation in wing shape proved to be extremely informative in interpreting variation within the $B$. dorsalis complex. 
Genetic, cytogenetic and molecular analyses of $B$. dorsalis complex specimens collected across the geographical range were carried out in participating laboratories in Asia, Australia and Europe:

Cytogenetics: One of the objectives was to identify and evaluate cytogenetic tools that could help to resolve the taxonomic status of the five taxa under study, focusing on chromosomal rearrangements, especially inversions. For this purpose, mitotic and polytene chromosomes were analysed from colonized specimen representing $B$. dorsalis s.s., B. papayae, B. philippinensis, B. invadens and B. carambolae. Analysis of mitotic karyotypes could not detect any differences among these five taxa (Yesmin and Clyde 2012, Yesmin 2013, Augustinos et al. 2014, Augustinos et al. 2015), showing that all had the typical $B$. dorsalis s.s. karyotype as previously described by Hunwattanakul and Baimai (1994). Polytene chromosome maps were developed for the first time of a member of the $B$. dorsalis complex, i.e. B. dorsalis s.s. (Zacharopoulou et al. 2011a). Subsequent analysis showed that the five members of the complex do not present any chromosomal rearrangements that could be used as diagnostic characters and therefore these taxa can be regarded as homosequential (Augustinos et al. 2014, 2015). Although B. carambolae presented the same mitotic and polytene chromosome karyotype as the other members of the complex, the presence of a high number of minor asynapses in $\mathrm{F}_{1}$ hybrids of $B$. dorsalis s.s. $\times$ B . carambolae crosses may indicate the presence of small differences in the chromosomal organization among the parental entities. However, these observations cannot be regarded as diagnostic at the species level (Augustinos et al. 2014).

Microsatellites: Microsatellite DNA markers derived from $B$. dorsalis s.s. were tested on populations of $B$. dorsalis s.s. from Bangladesh, Cambodia, China (multiple populations), Hawaii (two populations), Laos, Malaysia, Taiwan, and Thailand (multiple populations) (Shi et al. 2012, Krosch et al. 2013, Aketarawong et al. 2011, 2014a). The same set of markers combined with microsatellite markers derived from $B$. papayae were used to compare populations of $B$. dorsalis and $B$. papayae from the Thai/Malay Peninsula (Krosch et al. 2013, Aketarawong et al. 2014b). No genetic isolation was found between the $B$. dorsalis and $B$. papaya populations, supporting the hypothesis that both are the same entity. On the other hand, microsatellite markers, which amplify for $B$. carambolae and $B$. dorsalis, showed different genetic clusters between these two species, although admixture populations were observed. Admixture is evidence that some gene flow (i.e. hybridisation) may occur in the field between these species (Aketarawong et al. 2015).

Haplotype analysis: CO1 haplotype networks showed that common haplotypes were shared between $B$. dorsalis, B. papayae, B. philippinensis and B. invadens, but not with $B$. carambolae (Schutze et al. 2012b, 2015a). This supports the hypothesis that the first four taxa are a single biological species, while $B$. carambolae is distinct.

Phylogenetic analysis: A phylogenetic study using six neutral genetic markers found that $B$. carambolae could be resolved as a monophyletic clade from the other four target species, which were mixed together as an unresolved comb (Boykin et al. 2014, Schutze et al. 2015a). 
Based on genetic, cytogenetic, pheromonal, morphometric and behavioural data, which repeatedly showed no or only minor variation between $B$. dorsalis, $B$. invadens, $B$. papayae, and B. philippinensis, formal taxonomic name changes were made. B. philippinensis was made a junior synonym of B. papayae by Drew and Romig (2013). Subsequently, also $B$. papayae and $B$. invadens were synonymised with $B$. dorsalis (Schutze et al. 2015b, Hee et al. 2015b), while the status of B. carambolae has not been altered. This means that only $B$. dorsalis and $B$. carambolae remain as scientifically valid names. The name changes have been widely accepted by national and regional plant protection organizations around the world, the Secretariat of the International Plant Protection Convention and the FAO (http://www.fao.org/news/story/en/item/262972/icode/).

In the works of Drew and Romig (2013), San Jose et al. (2013) and Schutze et al. (2015b) new morphological descriptions of the target taxa are provided. However, the use of morphology alone is not sufficient for definitive diagnosis of $B$. carambolae and $B$. dorsalis, but molecular and pheromone markers are now available to distinguish them. Molecular protocols using neutral genetic markers to distinguish the two species from each other, and from other closely related taxa, are provided in Boykin et al. (2014). Microsatellite markers which amplify for both species and which are used in population genetic studies, are provided in Aketarawong et al. (2015). The Y-specific marker will also separate the two species. For adult flies, the presence of the ME metabolites DMP and E-CF in the male rectal gland following ME feeding can be used to discriminate $B$. dorsalis from $B$. carambolae (which produces only E-CF) (Tan and Nishida 1996, Wee et al. 2007, Wee and Tan 2007).

The knowledge and gaps identified at the start of the CRP, as well as the progress by the end of the CRP in addressing the gaps identified for the Bactrocera dorsalis complex are summarized in Table 2.

\subsection{Ceratitis FAR Complex Situation Analysis}

The Afro-tropical fruit flies Ceratitis fasciventris, C. anonae and C. rosa (i.e. the Ceratitis FAR complex), together with $C$. capitata and $C$. cosyra, are considered major horticultural pests of that region (White and Elson-Harris 1994, De Meyer 200la). These species are of quarantine significance (EPPO/CABI 1997) as they are highly polyphagous and damage a wide range of unrelated wild and cultivated crops (De Meyer et al. 2002), resulting in enormous economic losses wherever they occur (Barnes 2000, De Meyer 2001b). They have different distribution patterns that partially overlap, resulting in sympatric occurrence in particular areas.

Ceratitis rosa, $C$. fasciventris and $C$. anonae were considered the three members of the Ceratitis FAR species complex (Virgilio et al. 2007a, 2007b). Taxonomically, C. fasciventris was initially considered a variety of C. rosa (Bezzi 1920) but has recently been recognized as a different entity with species status (De Meyer 2001a).

Unlike $C$. capitata, which has over the last century spread from its home range in East Africa and attained an almost world-wide distribution (Fletcher 1989, White 


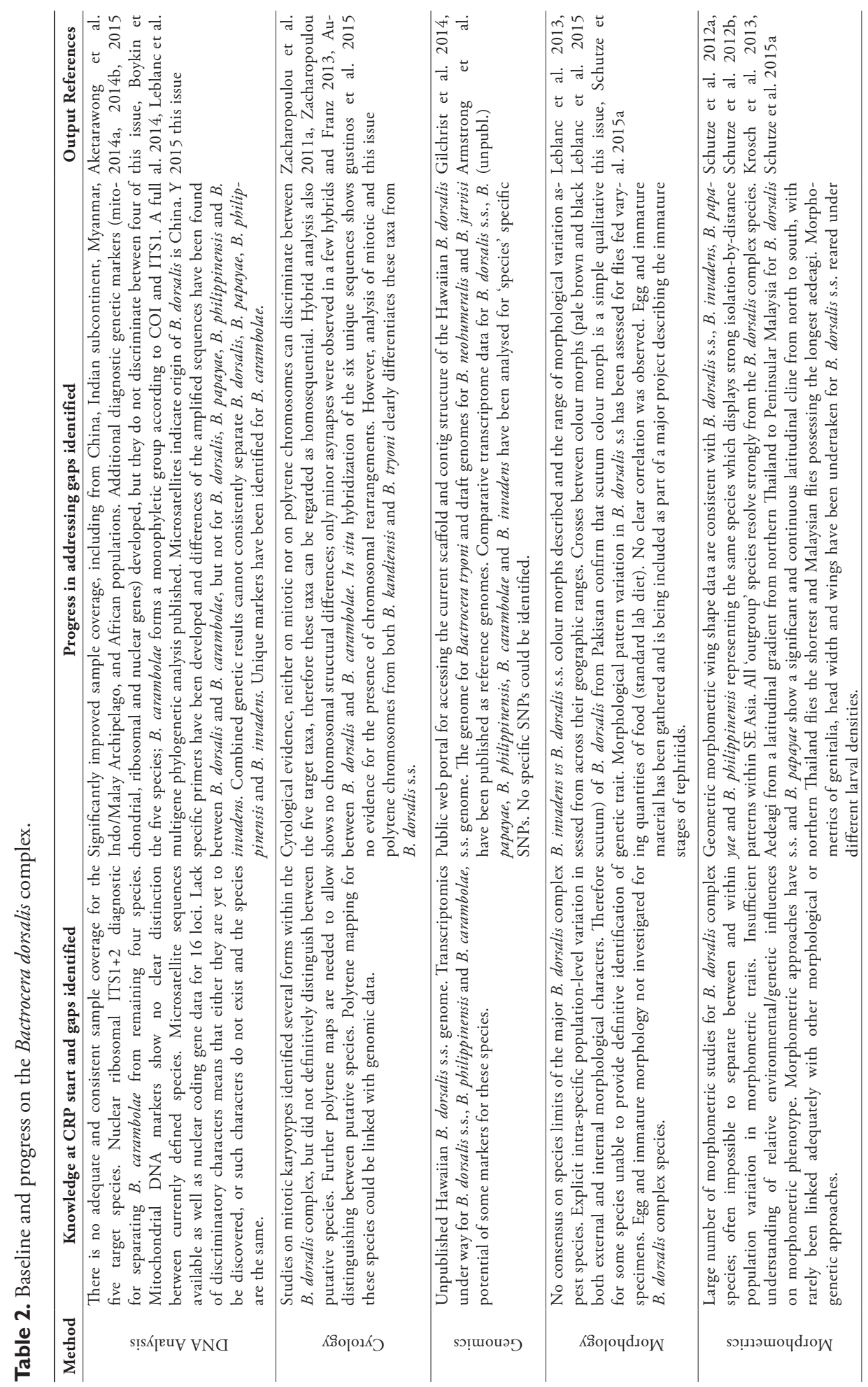




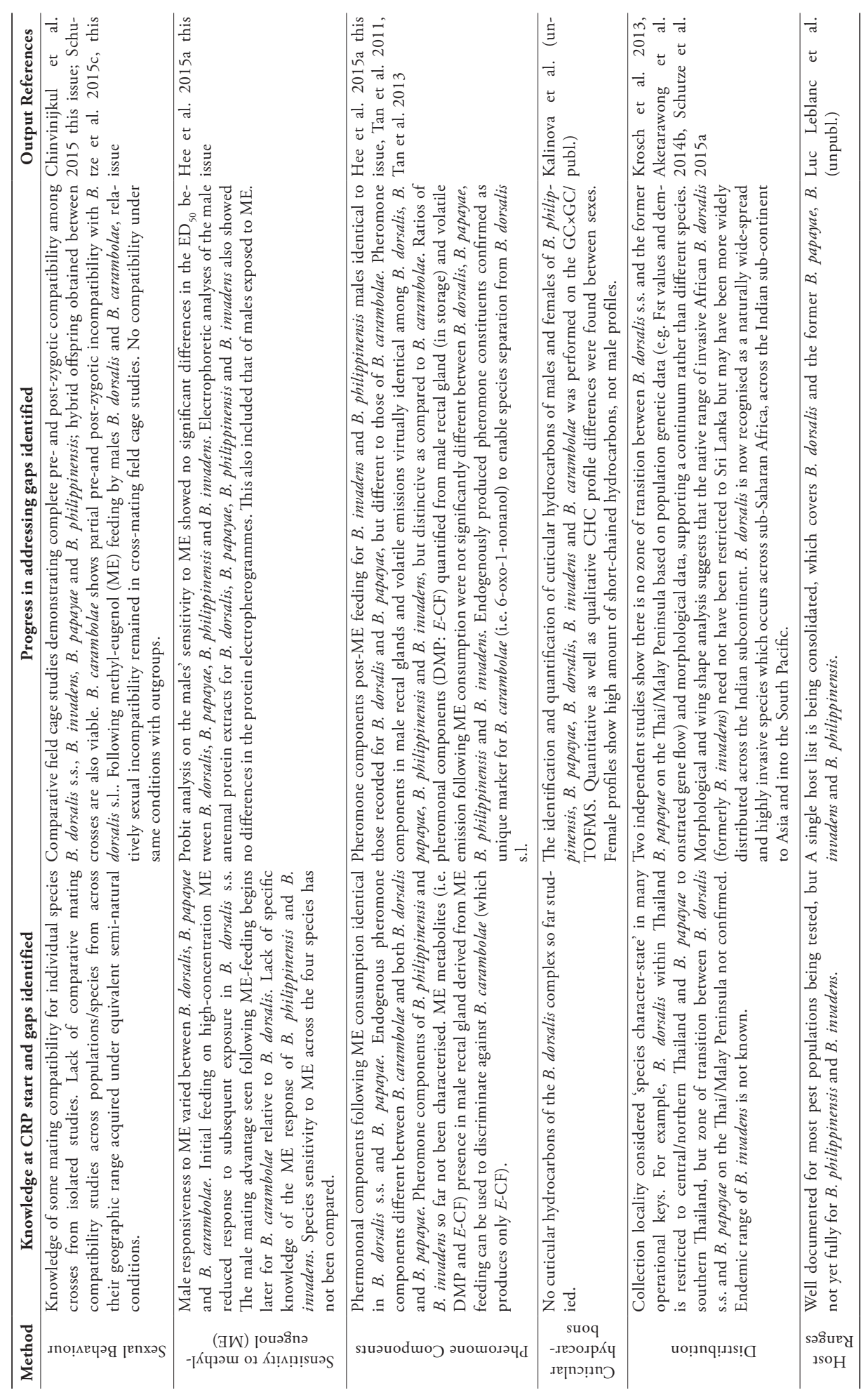


and Elson-Harris 1994, http://www-naweb.iaea.org/nafa/news/images/DistributionMediterranean-fruit-fly-Ceratitis-capitata.jpg), C. rosa, C. fasciventris and C. anonae have so far not been reported outside the African mainland (except for La Réunion and Mauritius) but are potentially invasive.

Due to the difficulty in distinguishing morphologically some members of the complex, especially females, a number of molecular approaches for species recognition were used (Baliraine et al. 2004, Barr et al. 2006, Virgilio et al. 2008). However, these diagnostic tools remained inadequate for quarantine purposes and much more robust molecular markers were needed.

\subsection{Outputs for Ceratitis FAR Complex}

Development of molecular diagnostics, using microsatellites (Delatte et al. 2013), revealed a more complex structure than the mere existence of three entities within the Ceratitis FAR complex. Five genotypic groups were identified (Virgilio et al. 2013) and later confirmed by morphological differences of the males (De Meyer et al. 2015a). Morphological diagnostics for male specimens of the five entities, called R1, R2 ( $C$. rosa type 1 and 2), F1, F2 (C. fasciventris type 1 and 2$)$ and $\mathrm{A}(C$. anonae) were developed. Morphometric diagnostics using wing landmarks were developed for both sexes to a certain extent (Van Cann et al. 2015). Microsatellites allowed distinction between the five entities. Cytological studies were restricted to one representative (F2) acting as a reference dataset (Drosopoulou, unpublished data).

Adult morphology and morphometry, pheromone, cuticular hydrocarbon and distributional data were collected that provide evidence for the specific status of all three formerly recognized taxonomic entities within the FAR complex (i.e. C. fasciventris, C. anonae, C. rosa) (Vaníčková et al. 2014, Břízová et al. 2015, De Meyer et al. 2015, Van Cann et al. 2015). More detailed studies were conducted for the two C. rosa types (R1, R2) (adult morphology and morphometry, pheromone, cuticular hydrocarbon, developmental physiology, behavioural, and ecological data), which provided evidence that the two C. rosa types represent two separate species (Tanga et al. 2015, Van Cann et al. 2015, Vaníčková et al. 2015b), of which one (currently referred to as R2) will be formally described. An altitudinal transect in Tanzania, where R1 and R2 occur in sympatry, confirmed that R1 is more tolerant to higher temperatures and R2 better adapted to colder environments (Mwatawala et al. 2015a). For the two C. fasciventris types (F1, F2) these additional studies could not be conducted as laboratory colonies of one of the two types could not be established, preventing experiments on developmental physiology and mating compatibility. Larval morphology did not provide evidence with regard to the specific status, except for $C$. fasciventris (F2) to some extent (Steck and Ekesi 2015). Moreover, as a spin-off of this research it was shown that characters previously considered diagnostic for differentiation between species and even between the genera Ceratitis and Bactrocera, proved to be variable. 
The knowledge and gaps identified at the start of the CRP, as well as the progress made by the end of the CRP in addressing the gaps identified for the Ceratitis FAR complex are summarized in Table 3 .

\subsection{Zeugodacus cucurbitae Situation Analysis}

The melon fly, Zeugodacus cucurbitae (initially referred to as Bactrocera (Zeugodacus) cucurbitae), is a major pest of cucurbit crops that has spread from its area of origin (South East Asia) across Africa, Hawaii, the Indian Ocean, Papua New Guinea and the Solomon Islands (Severin et al. 1914, Dhillon et al. 2005). In particular, it causes severe losses in food crops and restrictions to trade for some cucurbit crops.

Some populations were identified in Africa, islands in the Indian Ocean, Hawaii and South East Asia with different host use, which could indicate the existance of very closely related species. Although the SIT has been effectively applied against the melon fly in certain regions (Koyama et al. 2004), this issue needed to be resolved to enable the application of species-specific treatments such as the SIT against all populations in all regions.

\subsection{Outputs for Zeugodacus cucurbitae}

In spite of earlier observations and indication of different host-use by B. cucurbitae in different geographic regions, genetic studies using mitochondrial and nuclear markers indicated very low intraspecific variability worldwide. Population genetic studies using microsatellites were able to distinguish five major groups worldwide: African mainland and Seychelles, Réunion and Mauritius, Central Asia, SE Asia, and Hawaii (Virgilio et al. 2010). However no phylogeographic patterns could be discerned using cytogenetics analyses (Zacharopoulou et al. 2011b, 2013) or mitochondrial and nuclear gene fragments (total of $2764 \mathrm{bp}$ ) (Virgilio, unpublished data). The invasion history for the species on the African mainland was also reconstructed (Delatte et al. unpublished data).

Cross-mating experiments were conducted at the start of the CRP between populations of Mauritius, Seychelles and a genetic sexing strain of Hawaii and these indicated no mating incompatibility or sexual isolation (Sookar et al. 2013). Given this fact and the genetic assessments, it was decided there was no need for additional cross-mating studies.

Further studies, including host preference and microsatellite markers, did not show any relation between genetic structure and host plants (Virgilio et al. 2010, Sookar et al. 2013). It was concluded that there is no evidence of the existence of host races or cryptic species within B. cucurbitae. However, as a spin-off of the conducted research, recent studies on the higher phylogeny of dacines have shown that the higher taxonomic classification under which B. cucurbitae is placed, is a paraphyletic grouping, requiring a taxonomic change in generic placement (Krosch et al. 2012, Virgilio et 


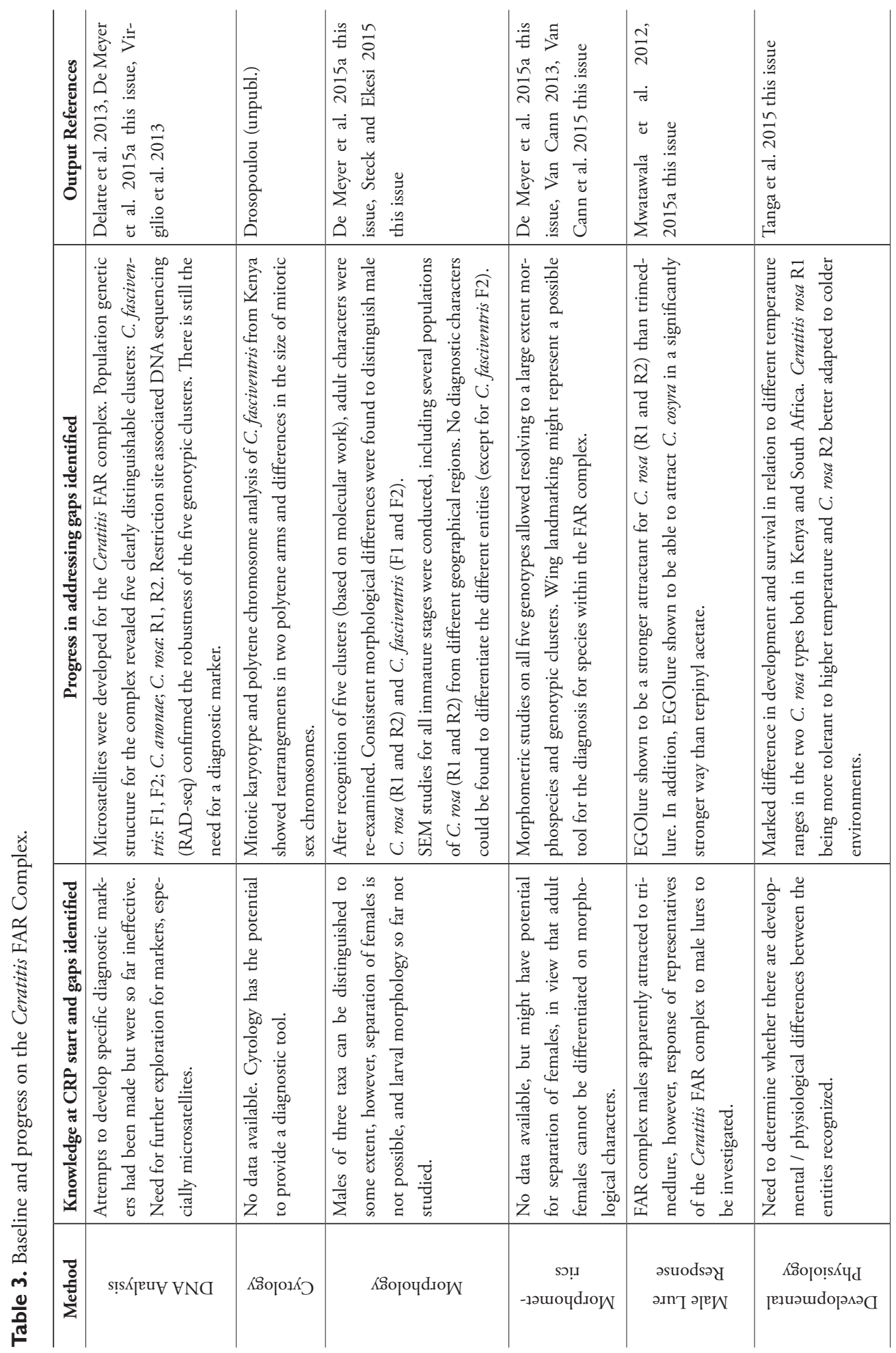




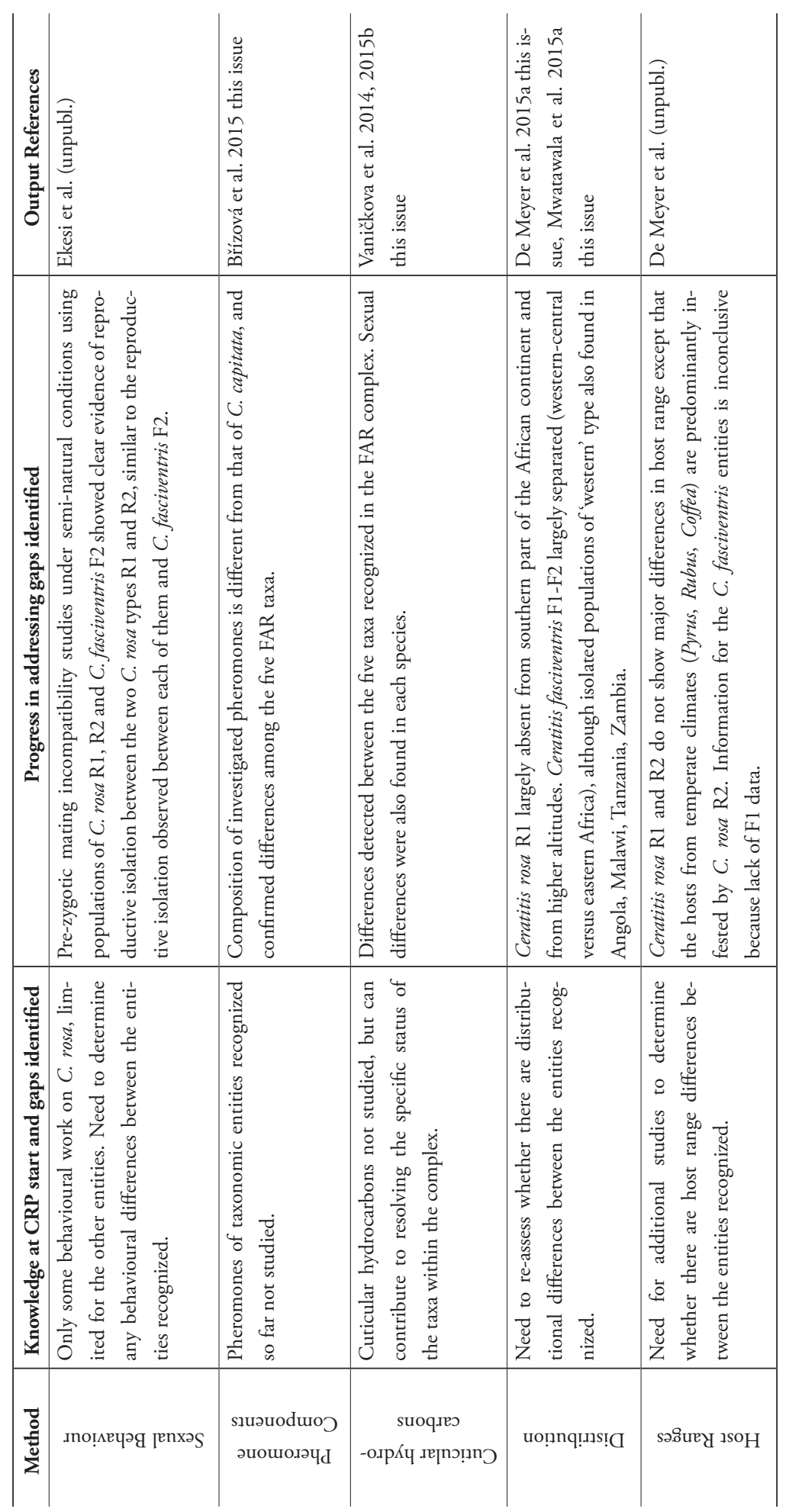




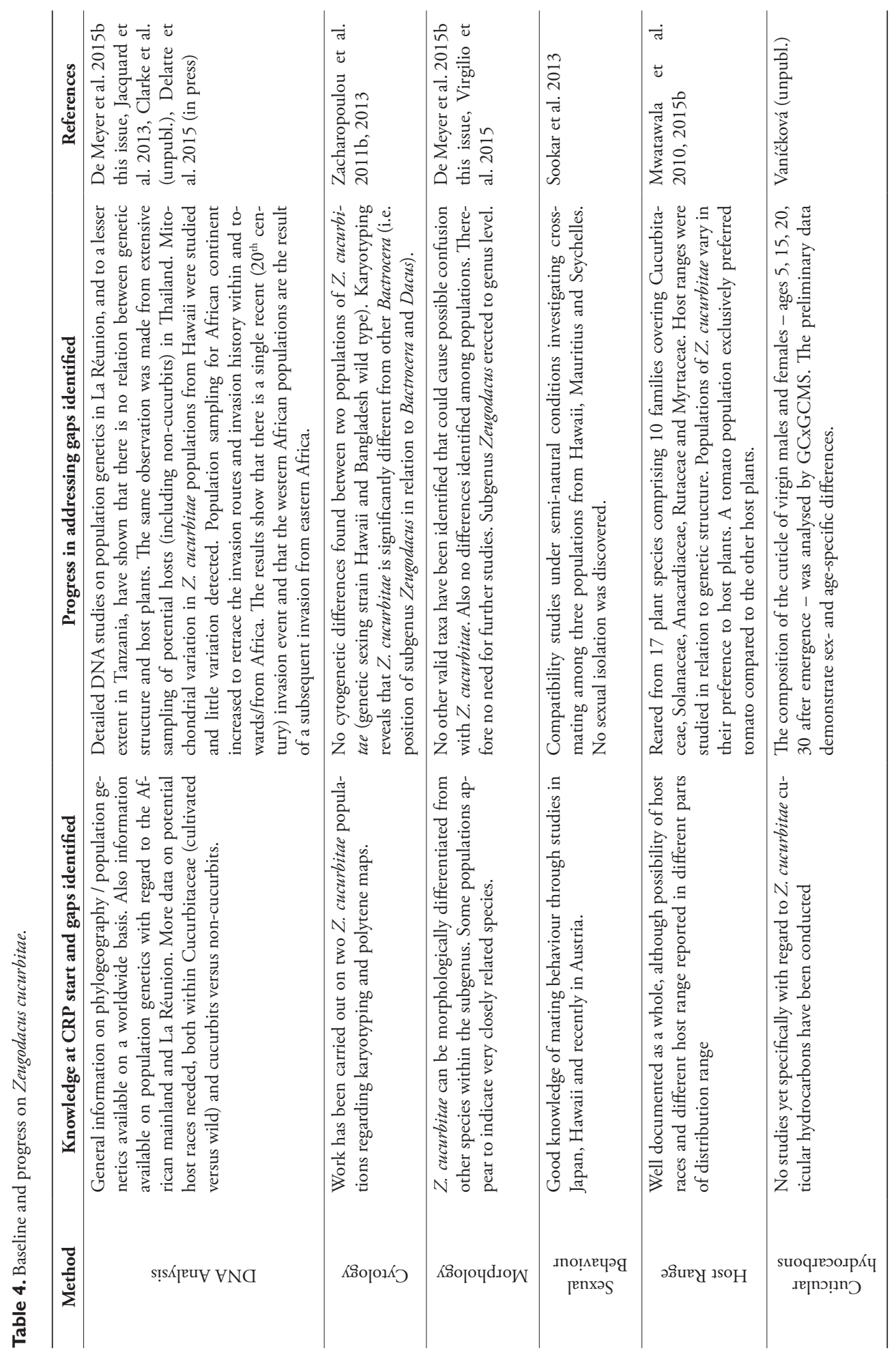


al. 2015). A nomenclatorial act has raised the subgenus Zeugodacus (as well as other subgenera belonging to the Zeugodacus group, sensu Drew 1989) to genus level. As a result, Bactrocera cucurbitae was put in a new generic combination: Zeugodacus cucurbitae, and should be referred to by this name from now onwards (Virgilio et al. 2015).

The knowledge and gaps identified at the start of the CRP, as well as the progress made by the end of the CRP in addressing the gaps identified for $Z$. cucurbitae are discussed in De Meyer et al. (2015b) and summarized in Table 4.

\section{Conclusion}

Following an integrative taxonomic approach, the biology, cytogenetics, ecology, morphology, genetics, and physiology of major pest tephritid cryptic species complexes is now much better understood. This increased knowledge has resulted in formal decisions on the species status of some taxa within these complexes, thus facilitating international horticultural trade and simplifing SIT application against pest species of these complexes. In the case of Anastrepha fraterculus it was shown that it consists of a complex of a number of different species of no monophyletic origin, with distinct geographic and ecological distributions in Latin America. Also for the Ceratitis FAR complex evidence has been provided for the existence of five different entities within this complex from the African region, i.e. Ceratitis anonae, C. rosa (R1 and a new species referred to as R2), while for $C$. fasciventris the biological limits between F1 and F2 are not fully resolved. On the other hand the Asian/African pest fruit flies B. papayae, $B$. philippinensis and $B$. invadens were shown to represent populations of $B$. dorsalis, while only $B$. carambolae remains a valid species for which molecular and pheromone markers are now available to distinguish it from $B$. dorsalis. Finally studies among populations throughout the geographic range of Bactrocera cucurbitae in Africa and the Asia/Pacific region showed no evidence for the existence of host races. However, the higher taxonomic classification under which Bactrocera cucurbitae is placed was found to be a paraphyletic grouping, requiring the elevation of the subgenus Zeugodacus to genus level. As a result, Bactrocera cucurbitae was put in a new generic combination: Zeugodacus cucurbitae.

\section{References}

Abraham S, Rull J, Mendoza M, Liendo MC, Devescovi F, Roriz AK, Kovaleski A, Segura DF, Vera MT (2014) Differences in sperm storage and remating propensity between adult females of two morphotypes of the Anastrepha fraterculus (Diptera: Tephritidae) cryptic species complex. Bulletin of Entomological Research 104: 376-382. doi: 10.1017/ S0007485314000200

Aketarawong N, Chinvinijkul S, Orankanok W, Guglielmino CR, Franz G, Malacrida AR, Thanaphum S (2011) The utility of microsatellite DNA markers for the evaluation of area- 
wide integrated pest management using SIT for the fruit fly, Bactrocera dorsalis (Hendel), control programs in Thailand. Genetica 139: 129-140. doi: 10.1007/s10709-010-9510-8 Aketarawong N, Guglielmino CR, Karam N, Falchetto M, Manni M, Scolari F, Gomulski LM, Gasperi G, Malacrida AR (2014a) The oriental fruit fly Bactrocera dorsalis ss in East Asia: disentangling the different forces promoting the invasion and shaping the genetic make-up of populations. Genetica 142: 201-213. doi: 10.1007/s10709-014-9767-4

Aketarawong N, Isasawin S, Thanaphum S (2014b) Evidence of weak genetic structure and recent gene flow between Bactrocera dorsalis ss and B. papayae, across Southern Thailand and West Malaysia, supporting a single target pest for SIT applications. BMC Genetics 15: 70. doi: 10.1186/1471-2156-15-70

Aketarawong N, Isasawin S, Sojikul P, Thanaphum S (2015) Gene flow and genetic structure of Bactrocera carambolae (Diptera, Tephritidae) among geographical differences and sister species, B. dorsalis, inferred from microsatellite DNA data. In: De Meyer M, Clarke AR, Vera MT, Hendrichs J (Eds) Resolution of Cryptic Species Complexes of Tephritid Pests to Enhance SIT Application and Facilitate International Trade. ZooKeys 540: 239-272. doi: 10.3897/zookeys.540.10058

Allwood AJ, Leblanc L (1996) Losses Caused by Fruit Flies (Diptera: Tephritidae) in Seven Pacific Island Countries. In: Allwood AJ, Drew RAI (Eds) Management of Fruit Flies in the Pacific: A regional symposium, Nadi, Fiji, 28-31 October 1996, 208-211.

Aluja M, Perez-Staples D, Macias Ordoñez R, Piñero J, McPheron B, Hernández Ortiz V (2003) Nonhost status of Citrus sinesis cultivar Valencia and C. paradisi cultivar Ruby Red to Mexican Anastrepha fraterculus (Diptera: Tephritidae). Journal of Economic Entomology 96: 1693-1703. doi: 10.1093/jee/96.6.1693

Armstrong KF, Ball SL (2005) DNA barcodes for biosecurity: invasive species identification. Philosophical Transactions of the Royal Society London 360: 1462, 1813-1823. doi: 10.1098/rstb.2005.1713

Augustinos AA, Drosopoulou E, Gariou-Papalexiou A, Bourtzis K, Mavragani-Tsipidou P, Zacharopoulou A (2014) The Bactrocera dorsalis species complex: comparative cytogenetic analysis in support of Sterile Insect Technique applications. BMC Genetics 15(Suppl 2): S16. doi: 10.1186/1471-2156-15-s2-s16

Augustinos AA, Drosopoulou E, Gariou-Papalexiou A, Asimakis ED, Cáceres C, Tsiamis G, Bourtzis K, Mavragani-Tsipidou P, Zacharopoulou A (2015) Cytogenetic and symbiont analysis of five members of the $B$. dorsalis complex (Diptera, Tephritidae): no evidence of chromosomal or symbiont-based speciation events. In: De Meyer M, Clarke AR, Vera MT, Hendrichs J (Eds) Resolution of Cryptic Species Complexes of Tephritid Pests to Enhance SIT Application and Facilitate International Trade. ZooKeys 540: 273-298. doi: 10.3897/ zookeys.540.9857

Baliraine FN, Bonizzoni M, Guglielmino CR, Osir EO, Lux SA, Mulaa FJ, Gomulski LM, Zheng L, Quilici S, Gasperi G, Malacrida AR (2004) Population genetics of the potentially invasive African fruit fly species, Ceratitis rosa and Ceratitis fasciventris (Diptera: Tephritidae). Molecular Ecology 13: 683-695. doi: 10.1046/j.1365-294X.2004.02105.x

Barnes BN (2000) Fruit flies of economic importance in South Africa: an overview. In: Price NS, Seewooruthun I (Eds) Proceedings of the Indian Ocean Commission Regional Fruit 
Fly Symposium, 5-9 June 2000, Flic en Flac, Mauritius, 101-107. [Commission de l'Ocèan Indien, Quatre Bornes, Mauritius]

Barr NB, Cui L, McPheron BA (2005) Molecular systematics of nuclear period in genus Anastrepha (Tephritidae). Annals of the Entomological Society of America 98: 173-180. doi: 10.1603/0013-8746(2005)098[0173:MSONGP]2.0.CO;2

Barr NB, Copeland RS, De Meyer M, Masiga D, Kibogo HG, Billah MK, Osir E, Wharton RA, McPheron BA (2006) Molecular diagnostics of economically important fruit fly species (Diptera: Tephritidae) in Africa using PCR and RFLP analyses. Bulletin of Entomological Research 96: 505-521.

Bezzi M (1920) Notes on Ethiopian fruit-flies of the family Trypaneidae, other than Dacus. Bulletin of Entomological Research 10: 211-272. doi: 10.1017/S000748530004414X

Bo W, Ahmad S, Dammalage T, Sto Tomas U, Wornoayporn V, Ul-Haq I, Cáceres C, Vreysen MJB, Hendrichs J, Schutze MK (2014) Mating compatibility between Bactrocera invadens and Bactrocera dorsalis (Diptera: Tephritidae). Journal of Economic Entomology 107: 623629. doi: 10.1603/EC13514

Boykin LM, Schutze MK, Krosch MN, Chomic A, Chapman TA, Englezou A, Armstrong KF, Clarke AR, Hailstones D, Cameron SL (2014) Multi-gene phylogenetic analysis of the south-east Asian pest members of the Bactrocera dorsalis species complex (Diptera: Tephritidae) does not support current taxonomy. Journal of Applied Entomology 138: 235-253. doi: $10.1111 /$ jen. 12047

Břízová R (2011) Analyses of male sex pheromone of Anastrepha fraterculus (Diptera: Tephritidae). M. Sc. Thesis. Institute of Chemical Technology, Prague, Czech Republic.

Břízová R, Mendonça AL, Vaníčková L, Lima-Mendonça A, da Silva CE, Tomčala A, Paranhos BAJ, Dias VS, Joachim-Bravo IS, Hoskovec M, Kalinová B, do Nascimento RR (2013) Pheromone analyses of the Anastrepha fraterculus (Diptera: Tephritidae) cryptic species complex. Florida Entomologist 96: 1107-1115. doi: 10.1653/024.096.0351

Břízová R, Vaníčková L, Fatarová M, Ekesi S, Hoskovec M, Kalinová B (2015) Analyses of volatiles produced by the African fruit fly species complex (Diptera, Tephritidae). In: De Meyer M, Clarke AR, Vera MT, Hendrichs J (Eds) Resolution of Cryptic Species Complexes of Tephritid Pests to Enhance SIT Application and Facilitate International Trade. ZooKeys 540: 385-404. doi: 10.3897/zookeys.540.9630

Cáceres C, Segura DF, Vera MT, Wornoayporn V, Cladera JL, Teal P, Sapountzis P, Bourtzis K, Zacharopoulou A, Robinson AS (2009) Incipient speciation revealed in Anastrepha fraterculus (Diptera; Tephritidae) by studies on mating compatibility, sex pheromones, hybridisation and cytology. Biological Journal of the Linnean Society 97: 152-165. doi: 10.1111/j.1095-8312.2008.01193.x

Canal NA, Hernández-Ortiz V, Tigrero Salas JO, Selivon D (2015) Morphometric study of third-instar larvae from five morphotypes of the Anastrepha fraterculus cryptic species complex (Diptera, Tephritidae). In: De Meyer M, Clarke AR, Vera MT, Hendrichs J (Eds) Resolution of Cryptic Species Complexes of Tephritid Pests to Enhance SIT Application and Facilitate International Trade. ZooKeys 540: 41-59. doi: 10.3897/zookeys.540.6012

Cavalloro R (Ed.) (1983) Fruit Flies of Economic Importance. A.A. Balkema, Rotterdam, Netherlands, xii +642 pp. 
Cayol JP, Coronado P, Taher M (2002) Sexual compatibility in medfly (Diptera: Tephritidae) from different origins. Florida Entomologist 85: 51-57. doi: 10.1653/0015-4040(2002)085[0051:SCIMDT]2.0.CO;2

Chinvinijkul S, Srikachar S, Kumjing P, Kimjong W, Sukamnouyporn W, Polchaimat N (2015) Inter-regional mating compatibility among Bactrocera dorsalis (Diptera, Tephritidae) populations in Thailand. In: De Meyer M, Clarke AR, Vera MT, Hendrichs J (Eds) Resolution of Cryptic Species Complexes of Tephritid Pests to Enhance SIT Application and Facilitate International Trade. ZooKeys 540: 299-311. doi: 10.3897/zookeys.540.6568

Cladera JL, Vilardi JC, Juri M, Paulin LE, Giardini MC, Gómez Cendra PV, Segura DF, Lanzavecchia SB (2014) Genetics and biology of Anastrepha fraterculus: research supporting the use of the sterile insect technique (SIT) to control this pest in Argentina. BioMedCentral Genetics 15(Suppl 2): S12. doi: 10.1186/1471-2156-15-s2-s12

Clarke AR, Armstrong KF, Carmichael AE, Milne JR, Raghu S, Roderick GK, Yeates DK (2005) Invasive phytophagous pests arising through a recent tropical evolutionary radiation: The Bactrocera dorsalis complex of fruit flies. Annual Review of Entomology 50: 293-319. doi: 10.1146/annurev.ento.50.071803.130428

Clarke AR, Schutze MK (2014) The complexities of knowing what it is you are trapping. In: Shelly T, Epsky N, Jang EB, Reyes-Flores J, Vargas R (Eds) Trapping and the Detection, Control, and Regulation of Tephritid Fruit Flies. Springer Dordrecht, Netherlands, 611-632. doi: 10.1007/978-94-017-9193-9_18

Delatte H, Virgilio M, Simiand C, Quilici S, De Meyer M (2013) Isolation and characterisation of sixteen microsatellite markers cross-amplifying in a complex of three African agricultural pests (Ceratitis rosa, C. anonae and C. fasciventris, Diptera: Tephritidae). Conservation Genetic Resources 5: 31-34. doi: 10.1007/s12686-012-9722-6

Delatte H, Ravigné V, De Meyer M, Virgilio M (2015) An approximate bayesian computation analysis of the introduction and range expansion of Zeugodacus cucurbitae (Diptera: Tephritidae) in Africa. Invasion Biology (in press).

De Meyer M (2001a) Distribution patterns and host-plant relationships within the genus Ceratitis MacLeay (Diptera: Tephritidae) in Africa. Cimbebasia 17: 219-228.

De Meyer M (2001b) On the identity of the Natal fruit fly Ceratitis rosa Karsch (Diptera, Tephritidae). Bulletin de l'Institut Royal des Sciences Naturelles de Belgique, Entomologie 71: 55-62.

De Meyer M, Copeland RS, Lux S, Mansell M, Wharton R, White IM, Zenz N (2002) Annotated check list of host plants for Afrotropical fruit flies (Diptera: Tephritidae) of the genus Ceratitis. Zoologische Documentatie Koninklijk Museum voor Midden Afrika 27: 1-92.

De Meyer M, Delatte H, Ekesi S, Jordaens K, Kalinová B, Manrakhan A, Mwatawala M, Steck G, Van Cann J, Vaníčková L, Břízová R, Virgilio M (2015a) An integrative approach to unravel the Ceratitis FAR (Diptera, Tephritidae) cryptic species complex: a review. In: De Meyer M, Clarke AR, Vera MT, Hendrichs J (Eds) Resolution of Cryptic Species Complexes of Tephritid Pests to Enhance SIT Application and Facilitate International Trade. ZooKeys 540: 405-427. doi: 10.3897/zookeys.540.10046

De Meyer M, Delatte H, Mwatawala M, Quilici S, Vayssières JF, Virgilio M (2015b) A review of the current knowledge on Zeugodacus cucurbitae (Coquillett) (Diptera, Tephritidae) in 
Africa, with a list of species included in Zeugodacus. In: De Meyer M, Clarke AR, Vera MT, Hendrichs J (Eds) Resolution of Cryptic Species Complexes of Tephritid Pests to Enhance SIT Application and Facilitate International Trade. ZooKeys 540: 539-557. doi: 10.3897/ zookeys.540.9672

Devescovi F, Abraham S, Passos Roriz AK, Nolazco N, Castañeda R, Tadeo E, Cáceres C, Segura DF, Vera MT, Joachim-Bravo I, Canal N, Rull J (2014) Ongoing speciation within the Anastrepha fraterculus cryptic species complex: the case of the Andean morphotype. Entomologia Experimentalis et Applicata 152: 238-247. doi: 10.1111/eea.12219

Dhillon MK, Singh R, Naresh JS, Sharma HC (2005) The melon fruit fly, Bactrocera cucurbitae: A review of its biology and management. Journal of Insect Science 5: 40-56. doi: 10.1093/ jis $/ 5.1 .40$

Dias SV (2012) Compatibilidade de acasalamento de populaçóes do complexo Anastrepha fraterculus (Diptera: Tephritidae) do Brasil. MCs Thesis. Universidade Federal da Bahia, Salvador, Brasil.

Dias VS, Silva JG, Lima KM, Petitinga CSCD, Hernández-Ortiz V, Laumann RA, Paranhos BJ, Uramoto K, Zucchi RA, Joaquim-Bravo IS (2015) An integrative approach based on sexual behavior, morphology, and molecular genetics to understanding cryptic divergence in Brazilian species of the Anastrepha fraterculus complex (Diptera: Tephritidae). Biological Journal of Linnean Society (in press).

Drew RAI (1989) The tropical fruit flies (Diptera: Tephritidae: Dacinae) of the Australasian and Oceanian Regions. Memoirs of the Queensland Museum 26: 1-521.

Drew RAI, Hancock DL (1994) The Bactrocera dorsalis complex of fruit flies (Diptera: Tephritidae: Dacinae) in Asia. Bulletin of Entomological Research Supplement Series, Supplement No. 2, 68 pp.

Drew RAI, Tsuruta K, White IM (2005) A new species of pest fruit fly (Diptera: Tephritidae: Dacinae) from Sri Lanka and Africa. African Entomology 13: 149-154.

Drew RAI, Raghu S, Halcoop P (2008) Bridging the morphological and biological species concepts: studies on the Bactrocera dorsalis (Hendel) complex (Diptera: Tephritidae: Dacinae) in South-east Asia. Biological Journal of the Linnean Society 93: 217-226. doi: 10.1111/j.1095-8312.2007.00952.x

Drew RAI, Romig MC (2013) Tropical Fruit Flies (Tephritidae: Dacinae) of South-East Asia. CAB International, Croydon, $664 \mathrm{pp}$.

Dutra VS, Ronchi-Telles B, Steck GJ, Silva GJ (2011) Egg morphology of Anastrepha spp. (Diptera: Tephritidae) in the fraterculus group using scanning electron microscopy. Annals of the Entomological Society of America 104: 16-24. doi: 10.1603/AN10105

Dutra VS, Ronchi-Teles B, Steck GJ, Silva JG (2012) Description of larvae of Anastrepha spp. (Diptera: Tephritidae) in the fraterculus group. Annals Entomological Society of America 105: 529-538. doi: 10.1603/AN11180

Dyck VA, Hendrichs J, Robinson (2005) Sterile Insect Technique, Principles and Practice in Area-Wide Integrated Pest Management. Springer, Dordrecht, 797 pp.

Ebina T, Ohto K (2006) Morphological characters and PCR-RFLP markers in the interspecific hybrids between Bactrocera carambolae and B. papayae of the $B$. dorsalis species complex (Diptera: Tephritidae). Research Bulletin of Plant Protection Japan 42: 23-34. 
EPPO/CABI (1997) In: Smith IM, McNamara DG, Scott PR, Holderness M (Eds) Quarantine Pests for Europe. $2^{\text {nd }}$ edition. CAB International, Wallingford, UK.

Enkerlin WR (2005) Impact of fruit fly control programmes using the sterile insect technique. In: Dyck VA, Hendrichs J, Robinson AS (Eds) Sterile Insect Technique Principles and Practice in Area-Wide Integrated Pest Management. Springer, 651-676. doi: 10.1007/14020-4051-2_25

FAO/IAEA/USDA (2014) Product Quality Control for Sterile Mass-Reared and Released

Tephritid Fruit Flies, Version 6.0. International Atomic Energy Agency, Vienna, Austria, 164 pp.

Fletcher BS (1989) Life history strategies of tephritid fruit flies. In: Robinson AS, Hooper GH (Eds) Fruit Flies: Their Biology, Natural Enemies and Control, Vol. 3B. Elsevier, Amsterdam, Netherlands, 195-208.

Gilchrist AS, Shearman DCA, Frommer M, Raphael KA, Deshpande NP, Wilkins MR, Sherwin WB, Sved JA (2014) The draft genome of the pest tephritid fruit fly Bactrocera tryoni: resources for the genomic analysis of hybridising species. BMC Genomics 15(1): 1153. doi: $10.1186 / 1471-2164-15-1153$

Goday C, Selivon D, Perondini ALP, Graciano PG, Ruiz MF (2006) Cytological characterization of sex chromosomes and ribosomal DNA location in Anastrepha species (Diptera: Tephritidae). Cytogenetic and Genome Research 114: 70-76. doi: 10.1159/000091931

Gomes Silva J (2000) Estudos moleculares. In: Malavasi A, Zucchi RA (Eds) Moscas-das-frutas de importáncia econômica no Brasil. Conhecimento básico e aplicado. Holos Editora, Riber, Brazil, 29-39.

Gonçalves GB, Silva CE, Mendonça ADL, Vaníčková L, Tomčala A, Do Nascimento RR (2013) Pheromone communication in Anastrepha obliqua (Diptera: Tephritidae): A comparison of the volatiles and salivary gland extracts of two wild populations. Florida Entomologist 96: 1365-1374. doi: 10.1653/024.096.0416

Hee AKW, Ooi YS, Wee SL, Tan KH (2015a) Comparative sensitivity to methyl eugenol of four putative Bactrocera dorsalis complex sibling species - further evidence that they belong to one and same species $B$. dorsalis. In: De Meyer M, Clarke AR, Vera MT, Hendrichs J (Eds) Resolution of Cryptic Species Complexes of Tephritid Pests to Enhance SIT Application and Facilitate International Trade. ZooKeys 540: 313-321. doi: 10.3897/zookeys.540.6099

Hee AKW, Wee SL, Nishida R, Ono H, Hendrichs J, Haymer DS, Tan KH (2015b) Historical perspective on the synonymization of the four major pest species belonging to the Bactrocera dorsalis species complex (Diptera, Tephritidae). In: De Meyer M, Clarke AR, Vera MT, Hendrichs J (Eds) Resolution of Cryptic Species Complexes of Tephritid Pests to Enhance SIT Application and Facilitate International Trade. ZooKeys 540: 323-338. doi: 10.3897/ zookeys.540.6028

Hernández-Ortiz V, Aluja M (1993) Listado de especies del género neotropical Anastrepha (Diptera: Tephritidae) con notas sobre su distribución y plantas hospederas. Species list of the Neotropical genus Anastrepha (Diptera: Tephritidae) with notes on distribution and host plants. Folia Entomológica Mexicana 33: 88-105. 
Hernández-Ortiz V, Gomez Anaya JA, Sanchez S, McPheron BA, Aluja M (2004) Morphometric analysis of Mexican and South American populations of the Anastrepha fraterculus complex (Diptera: Tephritidae) and recognition of a distinct Mexican morphotype. Bulletin of Entomol Research 94: 487-499. doi: 10.1079/BER2004325

Hernández-Ortiz V, Bartolucci AF, Morales-Valles P, Frías D, Selivon D (2012) Cryptic species of the Anastrepha fraterculus complex (Diptera: Tephritidae): a multivariate approach for the recognition of South American morphotypes. Annals of the Entomological Society of America 105: 305-318. doi: 10.1603/AN11123

Hernández-Ortiz V, Canal NA, Tigrero Salas JO, Ruíz-Hurtado FM, Dzul-Cauich JF (2015) Taxonomy and phenotypic relationships of the Anastrepha fraterculus complex in the Mesoamerican and Pacific Neotropical dominions (Diptera, Tephritidae). In: De Meyer M, Clarke AR, Vera MT, Hendrichs J (Eds) Resolution of Cryptic Species Complexes of Tephritid Pests to Enhance SIT Application and Facilitate International Trade. ZooKeys 540: 95-124. doi: 10.3897/zookeys.540.6027

Hunwattanakul N, Baimai V (1994) Mitotic karyotypes of four species of fruit flies (Bactrocera) in Thailand. Kasetsart Journal of Natural Sciience 28: 142-148.

Jacquard C, Virgilio M, Quilici S, De Meyer M, Delatte H (2013) Population structuring of an economic important pest: the case of the fruit fly Bactrocera cucurbitae on the tropical island of La Réunion. Biological Invasions 15(4): 759-773. doi: 10.1007/s10530-012-0324-8

Juárez ML, Devescovi F, Břízová R, Bachmann G, Segura DF, Kalinová B, Fernández P, Ruiz MJ, Yang J, Teal PEA, Cáceres C, Vreysen MJB, Hendrichs J, Vera MT (2015) Evaluating mating compatibility within fruit fly cryptic species complexes and the potential role of sex pheromones in pre-mating isolation In: De Meyer M, Clarke AR, Vera MT, Hendrichs J (Eds) Resolution of Cryptic Species Complexes of Tephritid Pests to Enhance SIT Application and Facilitate International Trade. ZooKeys 540: 125-155. doi: 10.3897/zookeys. 540.6133

Koyama J, Kakinohana H, Miyatake T (2004) Eradication of the Melon Fly, Bactrocera cucurbitae, in Japan: Importance of behavior, ecology, genetics, and evolution. Annual Review of Entomology 49: 331-349. doi: 10.1146/annurev.ento.49.061802.123224

Krosch MN, Schutze MK, Armstrong KF, Graham GC, Yeates DK, Clarke AR (2012) A molecular phylogeny for the Tribe Dacini (Diptera: Tephritidae): Systematic and biogeographic implications. Molecular Phylogenetics \& Evolution 64: 513-523. doi: 10.1016/j. ympev.2012.05.006

Krosch MN, Schutze MK, Armstrong KF, Boontop Y, Boykin LM, Chapman TA, Englezou A, Cameron SL, Clarke AR (2013) Piecing together an integrative taxonomic puzzle: microsatellite, wing shape and aedeagus length analyses of Bactrocera dorsalis s.l. (Diptera: Tephritidae) find no evidence of multiple lineages in a proposed contact zone along the Thai/Malay Peninsula. Systematic Entomology 38: 2-13. doi: 10.1111/j.1365-3113.2012.00643.x

Lanzavecchia SB, Juri M, Bonomi A, Gomulski L, Scannapieco AC, Segura DF, Malacrida A, Cladera JL, Gasper G (2014) Microsatellite markers from the 'South American fruit fly' Anastrepha fraterculus: a valuable tool for population genetic analysis and SIT applications. BMC Genetics 15(Suppl 2): S13. doi: 10.1186/1471-2156-15-S2-S13 
Leblanc L, Hossain MA, Khan SA, San Jose M, Rubinoff D (2013) A preliminary survey of the fruit flies (Diptera: Tephritidae: Dacinae) of Bangladesh. Proceedings of the Hawaiian Entomological Society 45: 51-58.

Leblanc L, San Jose M, Barr N, Rubinoff D (2015) A phylogenetic assessment of the polyphyletic nature and intraspecific color polymorphism in the Bactrocera dorsalis complex (Diptera, Tephritidae). In: De Meyer M, Clarke AR, Vera MT, Hendrichs J (Eds) Resolution of Cryptic Species Complexes of Tephritid Pests to Enhance SIT Application and Facilitate International Trade. ZooKeys 540: 339-367. doi: 10.3897/zookeys.540.9786

Lima K (2015) Genetic characterization of Anastrepha fraterculus populations in Brazil. PhD Thesis, Universidade Estadual de Santa Cruz, Bahia, Brazil.

Ludeña B, Bayas R, Pintaud JC (2011) Phylogenetic relationships of Andean-Ecuadorian populations of Anastrepha fraterculus (Wiedemann 1830) (Diptera: Tephritidae) inferred from COI and COII gene sequences. Annales de la Société Entomologique de France 46(3-4): 344-350.

Malavasi A, Morgante JS (1982) Genetic variation in natural populations of Anastrepha (Diptera: Tephritidae). Revista Brasileira de Genetica 5: 263-278.

Manni M, Lima KM, Guglielmino CR, Lanzavecchia SB, Juri M, Vera T, Cladera J, Scolari F, Gomulski L, Bonizzoni M, Gasperi G, Gomez-Silva J, Malacrida AR (2015) Relevant genetic differentiation among Brazilian populations of Anastrepha fraterculus (Diptera, Tephritidae). In: De Meyer M, Clarke AR, Vera MT, Hendrichs J (Eds) Resolution of Cryptic Species Complexes of Tephritid Pests to Enhance SIT Application and Facilitate International Trade. ZooKeys 540: 157-173. doi: 10.3897/zookeys.540.6713

McPheron BA, Han H-Y, Silva JG, Norrbom AL (1999) Phylogeny of the genera Anastrepha and Toxotrypana (Trypetinae: Toxotrypanini) based upon 16S rRNA mitochondrial DNA sequences. In: Aluja M, Norrbom AL (Eds) Fruit flies (Tephritidae): phylogeny and evolution of behavior. Boca Raton, Florida, CRC Press, USA, 343-361.

Milet-Pinheiro P, Navarro DMA, De Aquino NC, Ferreira LL, Tavares RF, Da Silva RCC, Lima-Mendonça A, Vaníčková L, Mendonça AL, Do Nascimento RR (2015) Identification of male-borne attractants in Anastrepha fraterculus (Diptera: Tephritidae). Chemoecology 25(3): 115-122. doi: 10.1007/s00049-014-0180-3

Morgante JS, Malavasi A, Bush GL (1980) Biochemical systematics and evolutionary relationships of neotropical Anastrepha. Annals of the Entomological Society of America 73: 622-630. doi: 10.1093/aesa/73.6.622

Muraji M, Nakahara S (2002) Discrimination among pest species of Bactrocera (Diptera: Tephritidae) based on PCR-RFLP on the mitochondrial DNA. Applied Entomology and Zoology 37: 437-446. doi: 10.1303/aez.2002.437

Mwatawala M, Maerere A, Makundi RH, De Meyer M (2010) Incidence and host range of the melon fruit fly Bactrocera cucurbitae (Coquillett) (Diptera: Tephritidae) in Central Tanzania. International Journal of Pest Management 56(3): 265-273. doi: $10.1080 / 09670871003596792$

Mwatawala M, Virgilio M, Quilici S, Dominic M, De Meyer M (2012) Field evaluation of the relative attractiveness of EGOlure and trimedlure for African Ceratitis species (Dip- 
tera: Tephritidae). Journal of Applied Entomology 137(5): 392-397. doi: 10.1111/j.14390418.2012.01744.x

Mwatawala M, Virgilio M, Joseph J, De Meyer M (2015a) Niche partitioning among two Ceratitis rosa morphotypes and other Ceratitis pest species (Diptera, Tephritidae) along an altitudinal transect in Central Tanzania. In: De Meyer M, Clarke AR, Vera MT, Hendrichs J (Eds) Resolution of Cryptic Species Complexes of Tephritid Pests to Enhance SIT Application and Facilitate International Trade. ZooKeys 540: 429-442. doi: 10.3897/zookeys.540.6016

Mwatawala M, Kudra A, Mkiga A, Godfrey E, Jeremiah S, Virgilio M, De Meyer M (2015b) Preference of Zeugodacus cucurbitae (Coquillett) for three commercial fruit vegetable hosts in natural and semi natural conditions. Fruits 70(6): 333-339. doi: 10.1051/fruits/2015034

Naeole CKM, Haymer DS (2003) Use of oligonucleotide arrays for molecular taxonomic studies of closely related species in the oriental fruit fly (Bactrocera dorsalis) complex. Molecular Ecology Notes 3: 662-665. doi: 10.1046/j.1471-8286.2003.00545.x

Norrbom AL, Kim K (1988) A list of the reported host plants of the species of Anastrepha (Diptera: Tephritidae). USDA-APHIS-PPQ. (Publication 81-52). USDA APHIS Plant Protection and Quarantine, Beltsville, MD, USA.

Norrbom AL, Zucchi RA, Hernández-Ortiz V (1999) Phylogeny of the genera Anastrepha and Toxotrypana (Trypetinae: Toxotrypanini) based on morphology. In: Aluja M, Norrbom AL (Eds) Fruit flies (Tephritidae): phylogeny and evolution of behavior. Boca Raton, Florida, CRC Press, USA, 299-342.

Norrbom AL (2004) Fruit fly (Tephritidae) host plant database. http://www.sel.barc.usda.gov/ diptera/tephriti/tephriti.htm [accessed 21 Oct, 2015]

Perre P, Jorge LR, Lewinsohn TM, Zucchi RA (2014) Morphometric differentiation of fruit fly pest species of the Anastrepha fraterculus group (Diptera: Tephritidae). Annals of the Entomological Society of America 107(2): 490-495. doi: 10.1603/AN13122

Prezotto LF (2008) Analise do ITS1 do DNA ribossomico em especies do complexo Anastrepha fraterculus. M. Sc. Thesis. Instituto de Biociências da Universidade de São Paulo, Brasil.

Rull J, Abraham S, Kovaleski A, Segura DF, Islam A, Wornoayporn V, Dammalage T, Santo Tomas U, Vera MT (2012) Random mating and reproductive compatibility among Argentinean and southern Brazilian populations of Anastrepha fraterculus (Diptera: Tephritidae). Bulletin of Entomological Research 102: 435-443. doi: 10.1017/S0007485312000016

Rull J, Abraham S, Kovaleski A, Segura DF, Mendoza M, Liendo MC, Vera MT (2013) Evolution of pre-zygotic and post-zygotic barriers to gene flow among three cryptic species within the Anastrepha fraterculus complex. Entomologia Experimentalis et Applicata 148: 213-222. doi: 10.1111/eea.12094

San Jose M, Leblanc L, Geib SM, Rubinoff D (2013) An evaluation of the species status of Bactrocera invadens (Drew, Tsuruta and White) and the systematics of the Bactrocera dorsalis (Diptera: Tephritidae) complex. Annals of the Entomological Society of America 106(6): 684-694. doi: 10.1603/AN13017

Schlick-Steiner BC, Steiner FM, Seifert B, Stauffer C, Christian E, Crozier RH (2010) Integrative taxonomy: a multisource approach to exploring biodiversity. Annual Review of Entomology 55: 421-438. doi: 10.1146/annurev-ento-112408-085432 
Schutze MK, Jessup A, Clarke AR (2012a) Wing shape as a potential discriminator of morphologically similar pest taxa within the Bactrocera dorsalis species complex (Diptera: Tephritidae). Bulletin of Entomological research 102: 103-111. doi: 10.1017/S0007485311000423

Schutze MK, Krosch MN, Armstrong KF, Chapman TA, Englezou A, Chomič A, Cameron S, Hailstones DL, Clarke AR (2012b) Population structure of Bactrocera dorsalis s.s., B. papayae and B. philippinensis (Diptera: Tephritidae) in southeast Asia: evidence for a single species hypothesis using mitochondrial DNA and wing-shape data. BMC Evolutionary Biology 12: 130. doi: 10.1186/1471-2148-12-130

Schutze MK, Jessup A, Ul-Haq I, Vreysen MJB, Wornoayporn V, Vera MT, Clarke AR (2013) Mating compatibility among four pest members of the Bactrocera dorsalis fruit fly species complex (Diptera: Tephritidae). Journal of Economic Entomology 106: 695-707. doi: 10.1603/EC12409

Schutze MK, Mahmood K, Pavasovic A, Bo W, Newman J, Clarke AR, Krosch MN, Cameron SL (2015a) One and the same: integrative taxonomic evidence that the African Invasive Fruit Fly Bactrocera invadens (Diptera: Tephritidae), is the same species as the Oriental Fruit Fly Bactrocera dorsalis. Systematic Entomology 40: 472-486. doi: 10.1111/syen.12114

Schutze MK, Aketarawong N, Amornsak W, Armstrong K, Augustinos A, Barr N, Bo W, Bourtzis K, Boykin L, Cáceres C, Cameron S, Chapman T, Chinvinijkul S, Chomič A, De Meyer M, Drosopoulou E, Englezou A, Ekesi S, Gariou-Papalexiou A, Geib S, Hailstones D, Hasanuzzaman H, Haymer D, Hee A, Hendrichs J, Jessup A, Ji Q, Khamis F, Krosch M, Leblanc L, Mahmood K, Malacrida A, Mavragani-Tsipidou P, Mwatawala M, Nishida R, Ono H, Reyes J, Rubinoff D, San Jose M, Shelly T, Srikachar S, Tan K, Thanaphum S, Ul-Haq I, Vijaysegaran S, Wee S, Yesmin F, Zacharopoulou A, Clarke AR (2015b) Synonymization of key pest species within the Bactrocera dorsalis species complex (Diptera: Tephritidae): taxonomic changes based on a review of 20 years of integrative morphological, molecular, cytogenetic, behavioural, and chemoecological data. Systematic Entomology 40: 456-471. doi: 10.1111/syen.12113

Schutze MK, Dammalage T, Jessup A, Vreysen MJB, Wornoayporn V, Clarke AR (2015c) Effects of laboratory colonization on Bactrocera dorsalis (Diptera, Tephritidae) mating behaviour: 'what a difference a year makes'. In: De Meyer M, Clarke AR, Vera MT, Hendrichs J (Eds) Resolution of Cryptic Species Complexes of Tephritid Pests to Enhance SIT Application and Facilitate International Trade 540: 369-383. doi: 10.3897/ zookeys.540.9770

Segura DF, Vera MT, Rull J, Wornoayporn V, Islam A, Robinson AS (2011) Assortative mating among Anastrepha fraterculus (Diptera: Tephritidae) hybrids from two distinct populations as a possible route to radiation of the fraterculus cryptic species group. Biological Journal of the Linnean Society 102: 346-354. doi: 10.1111/j.1095-8312.2010.01590.x

Selivon D (1996) Estudo sobre a diferenciação populacional em Anastrepha fraterculus (Wiedemann) (Diptera, Tephritidae). Doctoral Thesis, Departamento de Biologia, Universidade de São Paulo, São Paulo, Brasil.

Selivon D, Perondini ALP, Morgante JS (1999) Haldane's rule and other aspects of reproductive isolation observed in the Anastrepha fraterculus Complex (Diptera: Tephritidae). Genetics and Molecular Biology 22: 507-510. doi: 10.1590/S1415-47571999000400007 
Selivon D, Vretos C, Fontes L, Perondini ALP (2004) New variant forms in the Anastrepha fraterculus complex (Diptera, Tephritidae). In: Barnes (Ed.) Proceedings of the 6th International Symposium on Fruit Flies of Economic Importance, 6-10 May 2002, Stellenbosch, South Africa. Isteg ScientiPc Publications, Irene, South Africa, 253-258.

Selivon D, Perondini ALP, Morgante JS (2005) A genetic morphological characterization of two cryptic species of the Anastrepha fraterculus complex. (Diptera: Tephritidae). Annals of the Entomological Society of America 98: 367-381. doi: 10.1603/0013-8746(2005)098[ 0367:AGCOTC]2.0.CO;2

Selivon D, Perondini ALP (2007) Especies crípticas del complejo Anastrepha fraterculus en Brasil. Moscas de las frutas en Latinoamérica (Diptera: Tephritidae): Diversidad, biología y manejo. S y G Editores, México DF, 101-117.

Severin HHP, Severin HC, Hartung WJ (1914) The ravages, life history, weights of stages, natural enemies and methods of control of the Melon Fly (Dacus cucurbitae Coq.). Annals of the Entomological Society of America 7(3): 178-207. doi: 10.1093/aesa/7.3.177

Shi W, Kerdelhué C, Ye H (2012) Genetic structure and inferences on potential source areas for Bactrocrea dorsalis (Hendel) based on mitochondrial DNA and microsatellitemarkers. PLoS ONE 7(5): e37083. doi: 10.1371/journal.pone.0037083

Silva JG, Barr NB (2008) Recent advances in molecular systematics of Anastrepha Schiffner. In: Sugayam RL, Zucchi RA, Ovruski SM, Sivinski J (Eds) Fruit flies of economic importance: from basic to applied knowledge. Proc. $7^{\text {th }}$ International Symposium on Fruit Flies of Economic Importance. Press Color, Salvador, Brazil, 13-18.

Smith PT, Kambhampati S, Armstrong KA (2003) Phylogenetic relationships among Bactrocera species (Diptera: Tephritidae) inferred from mitochondrial DNA sequence. Molecular Phylogenetics and Evolution 26: 8-17. doi: 10.1016/S1055-7903(02)00293-2

Smith-Caldas MRB, McPheron BA, Silva JG, Zucchi RA (2001) Phylogenetic relationships among species of the fraterculus group (Anastrepha: Diptera: Tephritidae) inferred from DNA sequences of mitochondrial cytochrome oxidase 1. Neotropical Entomology 30: 565-573. doi: 10.1590/S1519-566X2001000400009

Solferini VN, Morgante JS (1987) Karyotype study of eight species of Anastrepha (Diptera, Tephritidae). Caryologia 40: 229-241. doi: 10.1080/00087114.1987.10797826

Sookar P, Ul-Haq I, Jessup A, McInnis D, Franz G, Wornoayporn V, Permalloo S (2013) Mating compatibility among Bactrocera cucurbitae (Diptera: Tephritidae) populations from three different origins. Journal of Applied Entomology 137: 69-74. doi: 10.1111/j.14390418.2010.01576.x

Steck GJ (1991) Biochemical systematics and population genetic structure of Anastrepha fraterculus and related species (Diptera: Tephritidae). Annals of the Entomological Society of America 84: 10-28. doi: 10.1093/aesa/84.1.10

Steck GJ (1999) Taxonomic status of Anastrepha fraterculus. The South American fruit fly, Anastrepha fraterculus (Wied.): advances in artificial rearing, taxonomic status and biological studies. International Atomic Energy Agency, Vienna, 13-20. [IAEA-TECDOC-1064]

Steck GJ, Sheppard WS (1993) Mitochondrial DNA variation in Anastrepha fraterculus. In: Aluja M, Liedo P (Eds) Fruit Flies, Biology and Management. Springer-Verlag, New York, 9-14. doi: 10.1007/978-1-4757-2278-9_2 
Steck GJ, Ekesi S (2015) Description of third instar larvae of Ceratitis fasciventris, $C$. anonae, $C$. rosa (FAR complex) and C. capitata (Diptera, Tephritidae). In: De Meyer M, Clarke AR, Vera MT, Hendrichs J (Eds) Resolution of Cryptic Species Complexes of Tephritid Pests to Enhance SIT Application and Facilitate International Trade. ZooKeys 540: 443-466. doi: 10.3897 /zookeys. 540.10061

Stone A (1942) The fruit flies of the genus Anastrepha. United States Department of Agriculture Miscellaneous Publication, Washington DC, USA, 439: 1-112.

Sutton BD, Steck GJ, Norrbom AL, Rodriguez EJ, Srivastava P, Alvarado NN, Colque F, Landa EY, Sánchez JJL, Quisberth E, Peñaranda EA, Clavijo PAR, Alvarez-Baca JK, Zapata TG, Ponce P (2015) Nuclear ribosomal internal transcribed spacer 1 (ITS1) variation in the Anastrepha fraterculus cryptic species complex (Diptera, Tephritidae) of the Andean region. In: De Meyer M, Clarke AR, Vera MT, Hendrichs J (Eds) Resolution of Cryptic Species Complexes of Tephritid Pests to Enhance SIT Application and Facilitate International Trade. ZooKeys 540: 175-191. doi: 10.3897/zookeys.540.6147

Tan KH, Nishida R (1996) Sex pheromone and mating competition after methyl eugenol consumption in Bactrocera dorsalis complex. In: McPheron BA, Steck GJ (Eds) Fruit Fly Pests - A World Assessment of their Biology and Management. St.Lucie Press, Florida, 147-153.

Tan KH, Nishida R (1998) Ecological significance of a male attractant in the defence and mating strategies of the fruit fly pest, Bactrocera papayae. Entomologia Experimentalis et Applicata 89: 155-158. doi: 10.1046/j.1570-7458.1998.00394.x

Tan KH, Tokushima I, Ono H, Nishida R (2011) Comparison of phenylpropanoid volatiles in male rectal pheromone gland after methyl eugenol consumption, and molecular phylogenetic relationship of four global pest fruit fly species: Bactrocera invadens, $B$. dorsalis, $B$. correcta and B. zonata. Chemoecology 21: 25-33. doi: 10.1007/s00049-010-0063-1

Tan KH, Wee SL, Ono H, Nishida R (2013) Comparison of methyl eugenol metabolites, mitochondrial COI, and rDNA sequences of Bactrocera philippinensis (Diptera: Tephritidae) with those of three other major pest species within the dorsalis complex. Applied Entomology and Zoology 48(3): 275-282. doi: 10.1007/s13355-013-0183-5

Tanga CM, Manrakhan A, Daneel JH, Mohamed SA, Khamis FM, Ekesi S (2015) Comparative analysis of development and survival of two Natal fruit fly Ceratitis rosa Karsch (Diptera, Tephritidae) populations from Kenya and South Africa. In: De Meyer M, Clarke AR, Vera MT, Hendrichs J (Eds) Resolution of Cryptic Species Complexes of Tephritid Pests to Enhance SIT Application and Facilitate International Trade. ZooKeys 540: 467-487. doi: 10.3897/zookeys.540.9906

Van Cann J (2013) A geometric morphometric answer to the Ceratitis FAR complex puzzle. M. Sc. Thesis, Faculty of Science, University of Antwerp, Antwerpt, Belgium.

Van Cann J, Virgilio M, Jordaens K, De Meyer M (2015) Wing morphometrics as a possible tool for the diagnosis of the Ceratitis fasciventris, C. anonae, C. rosa complex (Diptera, Tephritidae). In: De Meyer M, Clarke AR, Vera MT, Hendrichs J (Eds) Resolution of Cryptic Species Complexes of Tephritid Pests to Enhance SIT Application and Facilitate International Trade. ZooKeys 540: 489-506. doi: 10.3897/zookeys.540.9724

Vaníčková L (2012) Chemical ecology of fruit flies: genera Ceratitis and Anastrepha. PhD Thesis, Institute of Chemical Technology and Institute of Organic Chemistry and Biochemistry, Prague, Czech Republic. 
Vaníčková L, Svatoš A, Kroiss J, Kaltenpoth M, Nascimento RR, Hoskovec M, Břízová R, Kalinová B (2012) Cuticular hydrocarbons of the South American fruit fly Anastrepha fraterculus: variability with sex and age. Journal of Chemical Ecology 38: 1133-1142. doi: 10.1007/s10886-012-0177-8

Vaníčková L, Virgilio M, Tomčala A, Bř́zová R, Ekesi S, Hoskovec M, Kalinová B, Do Nascimento RR, De Meyer M (2014) Resolution of three cryptic agricultural pests (Ceratitis fasciventris, C. anonae, C. rosa, Diptera: Tephritidae) using cuticular hydrocarbon profiling. Bulletin of Entomological Research 104: 631-638. doi: 10.1017/S0007485314000406

Vaníčková L, Břízová R, Mendonça AL, Pompeiano A, Do Nascimento RR (2015a) Intraspecific variation of cuticular hydrocarbon profiles in the Anastrepha fraterculus (Diptera: Tephritidae) species complex. Journal of Applied Entomology. doi: 10.1111/jen.12204

Vaníčková L, Břizova R, Pompeiano A, Ekesi S, De Meyer M (2015b) Cuticular hydrocarbons corroborate the distinction between lowland and highland Natal fruit fly (Tephritidae, Ceratitis rosa) populations. In: De Meyer M, Clarke AR, Vera MT, Hendrichs J (Eds) Resolution of Cryptic Species Complexes of Tephritid Pests to Enhance SIT Application and Facilitate International Trade. ZooKeys 540: 507-524. doi: 10.3897/zookeys.540.9619

Vaníčková L, Břízová R, Pompeiano A, Ferreira LL, de Aquino NC, Tavares RF, Rodriguez LD, Mendonça AL, Canal NA, do Nascimento RR (2015c) Characterisation of the chemical profiles of Brazilian and Andean morphotypes belonging to the Anastrepha fraterculus complex (Diptera, Tephritidae). In: De Meyer M, Clarke AR, Vera MT, Hendrichs J (Eds) Resolution of Cryptic Species Complexes of Tephritid Pests to Enhance SIT Application and Facilitate International Trade. ZooKeys 540: 193-209. doi: 10.3897/zookeys.540.9649

Vaníčková L, Hernández-Ortiz V, Bravo ISJ, Dias V, Roriz AKP, Laumann RA, Mendonça AL, Jordão Paranhos BA, do Nascimento RR (2015d) Current knowledge of the species complex Anastrepha fraterculus (Diptera, Tephritidae) in Brazil. In: De Meyer M, Clarke AR, Vera MT, Hendrichs J (Eds) Resolution of Cryptic Species Complexes of Tephritid Pests to Enhance SIT Application and Facilitate International Trade. ZooKeys 540: 211-237. doi: 10.3897/zookeys.540.9791

Vera MT, Cáceres C, Wornoayporn V, Islam A, Robinson AS, de la Vega MH, Hendrichs J, Cayol JP (2006) Mating incompatibility among populations of the South American fruit fly Anastrepha fraterculus (Wied.) (Diptera: Tephritidae). Annals of the Entomological Society of America 99: 387-397. doi: 10.1603/0013-8746(2006)099[0387:MIAPOT]2.0.CO;2

Virgilio M, Backeljau T, De Meyer M (2007a) FAR complex and barcoding. 2nd International Barcode of Life Conference, Taipei, Taiwan, 142.

Virgilio M, Backeljau T, De Meyer M (2007b) Incongruence of phylogenetic signals and shared polymorphisms prevent the molecular characterization of the Ceratitis fasciventris, $C$. anonae, C. rosa complex (Diptera: Tephritidae). Abstract of 11th Congress of the European Society for Evolutionary Biology, Upsalla, Sweden, 520.

Virgilio M, Backeljau T, Barr N, De Meyer M (2008) Molecular evaluation of nominal species in the Ceratitis fasciventris, C. anonae, C. rosa complex (Diptera: Tephritidae). Molecular Phylogenetics and Evolution 48: 270-280. doi: 10.1016/j.ympev.2008.04.018

Virgilio M, Delatte H, Backeljau T, De Meyer M (2010) Macrogeographic population structuring in the cosmopolitan agricultural pest Bactrocera cucurbitae (Diptera: Tephritidae). Molecular Ecology 19: 2713-2724. doi: 10.1111/j.1365-294X.2010.04662.x 
Virgilio M, Delatte H, Quilici S, Backeljau T, De Meyer M (2013) Cryptic diversity and gene flow among three African agricultural pests: Ceratitis rosa, Ceratitis fasciventris and Ceratitis anonae (Diptera, Tephritidae). Molecular Ecology 22: 2526-2539. doi: 10.1111/mec.12278

Virgilio M, Jordaens K, Verwimp C, White IM, De Meyer M (2015) Higher phylogeny of frugivorous flies (Diptera, Tephritidae, Dacini): Localised partition conflicts and a novel generic classification. Molecular Phylogenetics and Evolution 85: 171-179. doi: 10.1016/j. ympev.2015.01.007

Waterhouse DF (1993) Biological Control: Pacific Prospects - Supplement 2. ACIAR Monograph No. 20, viii, 138 pp.

Wee SL, Tan KH (2005) Evidence of natural hybridization between two sympatric sibling species of Bactrocera dorsalis complex based on pheromone analysis. Journal of Chemical Ecology 31: 845-858. doi: 10.1007/s10886-005-3548-6

Wee SL, Tan KH (2007) Temporal accumulation of phenylpropanoids in male fruit flies, Bactrocera dorsalis and B. carambolae (Diptera: Tephritidae) following methyl eugenol consumption. Chemoecology 12: 193-197. doi: 10.1007/PL00012668

Wee SL, Tan KH, Nishida R (2007) Pharmacophagy of methyl eugenol by males enhances sexual selection of Bactrocera carambolae (Diptera: Tephritidae). Journal of Chemical Ecology 33: 1272-1282. doi: 10.1007/s10886-007-9295-0

White IM, Elson-Harris MM (1994) Fruit flies of economic significance: their identification and bionomics. CAB International, Wallingford, Oxon, UK and The Australian Center for Agricultural Research, Canberra, 601 pp.

Yamada S, Selivon D (2001) rose, an eye color mutation in a species of the Anastrepha fraterculus complex (Diptera, Tephritidae). Annals of the Entomological Society of America 94: 592-595. doi: 10.1603/0013-8746(2001)094[0592:RAECMI]2.0.CO;2

Yesmin F, Clyde MM (2012) The chromosomes of the carambola fruit fly, Bactrocera carambolae (Diptera: Tephritidae): metaphase karyotype and polytene genome. GSTF Journal of BioScience 1: 10-15.

Yesmin F (2013) Chromosomes of Bactrocera papaya Drew \& Hancock and Bactrocera carambolae Drew \& Hancock (Diptera: Tephritidae): Mitotic metaphase karyotype and polytene genome. PhD Thesis, Malaysia.

Zacharopoulou A, Augustinos AA, Sayed WAA, Robinson AS, Franz G (2011a) Mitotic and polytene chromosomes analysis of the oriental fruit fly, Bactrocera dorsalis (Hendel) (Diptera: Tephritidae). Genetica 139: 79-90. doi: 10.1007/s10709-010-9495-3

Zacharopoulou A, Sayed WAA, Augustinos AA, Yesmin F, Robinson AS, Franz G (2011b) Analysis of mitotic and polytene chromosomes and photographic polytene chromosome maps in Bactrocera cucurbitae (Diptera: Tephritidae). Annals of the Entomological Society of America 104: 306-318. doi: 10.1603/AN10113

Zacharopoulou A, Franz G (2013) Genetic and cytogenetic characterization of genetic sexing strains of Bactrocera dorsalis and Bactrocera cucurbitae (Diptera: Tephritidae). Journal of Economic Entomology 106: 995-1003. doi: 10.1603/EC12379

Zucchi RA (2000) Espécies de Anastrepha, Sinonímias, Plantas Hospedeiras e Parasitóides. In: Malavasi A, Zucchi RA (Eds) Moscas-das-frutas de interesse econômico no Brasil: Conhecimento básico e aplicado. Holos, Ribeirão Preto, 41-48. 
Zucchi RA (2007) Diversidad, distribución y hospederos del género Anastrepha en Brasil. In: Hérnandez-Ortiz V (Ed.) Moscas de la fruta en Latinoámerica (Diptera: Tephritidae): Diversidad, biologia y manejo. S y G editores, Distrito Federal, 77-100.

Zucchi RA, Silva RA, Deus EDG (2011) Espécies de Anastrepha e seus hospedeiros na Amazônia brasileira. In: Silva RA, Lemos WP, Zucchi RA (Eds) Moscas-das-frutas na Amazônia brasileira: diversidade, hospedeiros e inimigos naturais. Embrapa Amapá, Macapá, 51-70.

Zucchi RA (2015) Fruit flies in Brazil - Anastrepha species their host plants and parasitoids. http://www.lea.esalq.usp.br/anastrepha

Zykova K (2013) Quantitative composition changes of sex pheromone in Anastrepha fraterculus depending on age. Thesis, Institute of Chemical Technology, Prague, Czech Republic. 